Studia Iexicographica, 15(2021) 28, STR. 181-220

Toni Marić, Anka Raič, Vedran Vidović, Mirela Šečić: Portali i baze podataka o elementima nematerijalne kulturne baštine na festivalima folklora

Stručni rad

\title{
Portali i baze podataka o elementima nematerijalne kulturne baštine na festivalima folklora
}

\author{
Toni Marić \\ Društvo za digitalizaciju tradicijske kulturne baštine Široki Brijeg \\ toni.maric@tel.net.ba \\ Anka Raič \\ Sekcija CIOFF-a BiH, Mostar \\ raicanka@gmail.com \\ Vedran Vidović ${ }^{(}$ \\ Udruga hrvatskih amaterskih kulturno-umjetničkih društava u $\mathrm{BiH}$, Mostar \\ vidovic.vedran@medjugorje.hr \\ Mirela Šečić \\ Federalno ministarstvo kulture i sporta, Sarajevo \\ mirela.secic@fmks.gov.ba
}

SAŽETAK: Rad opisuje način prikupljanja, obrade i digitalizacije materijala o nematerijalnoj kulturnoj baštini u Bosni i Hercegovini koja se prezentira na festivalima folklora te izgradnju multimedijalnih baza podataka i portala za njihovu promociju. Navedene aktivnosti pojedine elemente nematerijalne kulturne baštine i kulturno-umjetnička društva kao njihove baštinike čine vidljivijima i dostupnijima javnosti uz davanje dodatnoga poticaja samim baštinicima za njihovo prenošenje na mlade naraštaje. Opisano provodi Društvo za digitalizaciju tradicijske kulturne baštine iz Širokog Brijega $u$ suradnji s partnerima i samim baštinicima elemenata kroz dva projekta.

Prvi projekt, diple.org, realizira se s Udrugom hrvatskih amaterskih kulturno-umjetničkih društava u $\mathrm{BiH}$ i prezentira tradicijsku kulturnu baštinu Hrvata u $\mathrm{BiH}$, a drugi projekt, tkanica.org, prezentira baštinike, njihove elemente i festivale folklora u $\mathrm{BiH}$ koji djeluju u okrilju međunarodne organizacije CIOFF (International Council of Organizations of Folklore Festivals and Folk Arts) i realizira se sa Sekcijom CIOFF-a za BiH.

Projektima je do sada obuhvaćeno više od dvije stotine baštinika. Obrađeni su detaljniji podatci o sedam kulturno-umjetničkih društava, sedam festivala folklora, dva popisa jednog broja karakterističnih elemenata na lokalitetima kao i jedan popis vještina sviranja na sedam tradicijskih glazbala.

Realizacija dosadašnjega dijela projekta pokazala je kako su baštinici elemenata koji ulažu znatne napore $\mathrm{u}$ istraživanje na samom terenu o elementima nematerijalne kulturne baštine svojega kraja uspjeli održati kontinuitet u radu i dodatno skrenuti pozitivnu pozornost javnosti na svoju baštinu.

Ključne riječi: elementi nematerijalne kulturne baštine (NKB) u $\mathrm{BiH}$; baštinici elemenata NKB-a; baze podataka; digitalizacija

(D) https://orcid.org/0000-0002-0817-9346 [Toni Marić]

(1D) https://orcid.org/0000-0002-8013-4054 [Anka Raič]

(D) https://orcid.org/0000-0001-7645-8278 [Vedran Vidović]

(D) https://orcid.org/0000-0003-4264-8457 [Mirela Šečićc] 


\section{Uvod}

Tradicijska kulturna baština sastavni je dio pozitivnoga identiteta jednoga mjesta i ljudi koji u njemu žive. Nematerijalna kulturna baština (NKB) predstavlja njezin poseban segment. Današnji životni tempo stavlja razne izazove pred nastojanja da se NKB očuva i prenese na mlade naraštaje.

Namjera je ovoga teksta opisati rad na digitalizaciji sadržaja o NKB-u koju provodi Društvo za digitalizaciju tradicijske kulturne baštine (Društvo za DTKB) u suradnji s partnerima. ${ }^{1}$ Svojim aktivnostima Društvo za $\mathrm{DTKB}^{2}$ pridonosi većoj vidljivosti i dostupnosti pojedinoga elementa NKB-a i njegovu očuvanju u svakodnevici lokalne zajednica. UNESCO-ova konvencija iz 2003. godine o očuvanju nematerijalne kulturne baštine ${ }^{3}$ jasno definira uloge lokalnih zajednica, regija, države i međunarodne razine, odnosno UNESCO-a i nevladina sektora. Ovom je konvencijom definirano koje su aktivnosti u nadležnosti državnih institucija, a koje u domeni nevladina sektora. Izrada službenih popisa elemenata NKB-a i kandidiranje pojedinih elemenata na međunarodnu UNESCO-ovu listu isključivo je u domeni državnih institucija. Dio materijala koje obrađuje Društvo za DTKB sa svojim partnerima može poslužiti i kao pomoć pri izradi službenih popisa.

U nastavku rada nastojat ćemo pojasniti zašto je Društvo za DTKB krenulo s ovim aktivnostima. Društvo za DTKB nevladina je udruga koja u suradnji s partnerima pojedine elemente NKB-a čini vidljivijima i dostupnijima zainteresiranoj javnosti te ih nastoji popularizirati među mladima i prenijeti na nove generacije, čime se nastavila prisutnost Društva u lokalnoj zajednici kao dio pozitivne prepoznatljivosti mjesta iz kojega potječe.

Obrađeni i dostupni materijali mogu biti posebno korisni organizatorima događanja s tematikom tradicijske kulturne baštine, ali i gospodarstvenicima kao poticaj za implementaciju pojedinih elemenata u gospodarski samoodržive projekte.

Zbog ubrzanoga tempa života i promjene životnih navika u posljednjih nekoliko desetljeća ulogu tradicionalne obitelji u prijenosu s koljena na koljeno za znatan broj elemenata NKB-a preuzela su kulturno-umjetnička društva (KUD-ovi). ${ }^{4}$ Sami KUD-ovi, kao i njihovi pojedinačni članovi, danas su baštinici velikoga broja elemenata NKB-a. Mjesta na kojima KUD-ovi prezentiraju elemente NKB-a koje oni

1 Vladić-Mandarić, Miloš, Vidović 2020: 15-35.

2 http://drustvozadtkb.org/ (pristupljeno 20. V. 2021).

${ }^{3}$ UNESCO (2003): Konvencija o očuvanju nematerijalne kulturne baštine, Pariz, UNESCO, 17. listopada 2003.

4 Raič 2010: 170-183. 
baštine jesu festivali folklora, kojima baš iz toga razloga, kao i KUD-ovima, Društvo za DTKB posvećuje posebnu pozornost.

Većina članova Društva za DTKB uključena u ovaj projekt dolazi iz KUD-ova i njihovu tematiku izvrsno poznaje. ${ }^{5}$ Rad KUD-ova Društvo obrađuje u kontekstu cjelovitoga očuvanja tradicijske kulturne baštine. ${ }^{6}$ Gotovo svaki KUD baštini veći broj elemenata $\mathrm{NKB} \mathrm{a}^{7}$ od kojih se mnogi još uvijek ne nalaze na nekom od službenih popisa. Pojam elementi NKB-a u ovom radu ne odnosi se na neku javno obznanjenu regionalnu, državnu ili međunarodnu listu, nego na dijelove tradicijske kulturne baštine koje prakticiraju članovi KUD-ova, udruge koje se bave očuvanjem tradicijske kulturne baštine ili pojedinačni baštinici. Društvo za DTKB u suradnji sa samim baštinicima radilo je i na popisima jednoga broja karakterističnih elemenata NKB-a koje baštine određeni KUD-ovi ili grupe KUD-ova. ${ }^{8}$ Ovi popisi nose naziv »Popis jednog broja karakterističnih elemenata NKB-a« kako bi sugerirali da se ne radi o službenim popisima nego o cjelovitu prikazu NKB-a koji baštine članovi konkretnih KUD-ova na određenom lokalitetu. Također i ovi popisi mogu poslužiti kao dodatni materijali državnim institucijama za izradu određenih službenih popisa elemenata NKB-a koji su u njihovoj nadležnosti.

Rad nastoji i praktičnim brojkama potkrijepiti tezu kako KUD-ovi koji poklanjaju veću pozornost prikupljanju i obradi podataka o elementima NKB-a koje baštine, uspješnije zadržavaju kontinuitet u radu, a i dodatno skreću pozitivnu pozornost na svoj rad i mjesto iz kojega potječu.

Rad na digitalizaciji bilo je neophodno započeti definiranjem osnovne logičke strukture baze podataka, preciziranjem osnovnih objekata ili entiteta obrade o kojima će se prikupljati informacije, opisom podatka koji će se obrađivati, kao i relacijom/odnosom između pojedinih objekata. Također, razrađena je i metodologija prikupljanja, obrade, digitalizacije i prezentacije podataka s precizno definiranim ulogama sudionika tehničkih stručnjaka, baštinika, sakupljača i stručnjaka iz pojedinih područja elemenata NKB-a. ${ }^{9}$ U procesu se nastojalo kontinuirano zadržati angažirane baštinike kako bi se materijali mogli neprekidno dopunjavati.

Aktivnosti na digitalizaciji Društvo za DTKB provodi u suradnji s Udrugom hrvatskih amaterskih kulturno-umjetničkih društava u $\mathrm{BiH}(\mathrm{UHAKUD} \mathrm{u} \mathrm{BiH})^{10} \mathrm{i}$

\footnotetext{
5 Marić 2008: 157-159.

6 Marić, Ostojić, Marić 2010: 120-123.

7 Vidović 2015: 71-78.

8 Marić, Ivić, Miloš, Raič 2020: 247-283.

9 Isto.

${ }^{10}$ Vladić-Mandarić, Miloš, Vidović 2020: 15-35.
} 
Sekcijom CIOFF-a za BiH, ${ }^{11}$ krovnim udrugama KUD-ova i organizatora festivala folklora u $\mathrm{BiH}$ čiji članovi zajedno broje više tisuća baštinika različitih elemenata NKB-a u BiH.

U sklopu projekta diple.org ${ }^{12,13}$ koji provodi Društvo za DTKB u suradnji s UHAKUD-om u BiH predstavljeni su detaljniji prikazi obrađenih materijala o četirima KUD-ovima i trima festivalima folklora. Navedeni KUD-ovi članovi su UHAKUD-a u BiH. Festivale organiziraju članovi UHAKUD-a u BiH. Posebno je naveden i popis od 29 KUD-ova/udruga s područja Županije Zapadnohercegovačke koji su baštinici jedne od navedenih listi.

Posebno su predstavljena dva popisa nekih od karakterističnih elemenata NKB-a koje baštine članovi KUD-ova s dva lokaliteta. Opisane su inicijative i načini kako su nastali i što se na njima nalazi. Prvi je popis karakterističnih elemenata NKB-a naveden za područje širokobrijeških sela Župe Mostarski Gradac koje baštine članovi HKD-a Vrila, ${ }^{14}$ a u koje spadaju Dobrič, Donji Gradac, Gornji Gradac, Gostuša, Grabova Draga i Provo. Drugi popis karakterističnih elemenata NKB-a s područja Županije Zapadnohercegovačke koje baštini većina KUD-ova s područja Županije Zapadnohercegovačke donosi više detalja o pojedinačnim elementima. ${ }^{15}$

U sklopu projekta tkanica.org ${ }^{16,17}$ predstavljena su tri KUD-a, četiri festivala kao i popis vještina sviranja na sedam tradicijskih glazbala u $\mathrm{BiH}$ te popis samih tradicijskih glazbenika. O ovom dijelu projekta mogu se naći podatci i na službenim mrežnim stranicama UNESCO-a. ${ }^{18}$ Naglasak je u projektu stavljen na festivale folklora jer se na njima redovito okupljaju baštinici elemenata i prezentiraju ih široj javnosti. Elemente se nastoji opisati u njihovu prirodnom okruženju i uz materijalnu baštinu koja ih okružuje kako bi se dobio što cjelovitiji uvid u kontekst te baštine.

${ }^{11} \mathrm{CIOFF}{ }^{\circledR} \mathrm{BiH}$ (2020). 10 godina s vama CIOFF®, Mostar, USOFFTU u BiH/ Sekcija CIOFF® za $\mathrm{BiH}$.

12 www.diple.org (pristupljeno 20. V. 2021).

${ }^{13}$ https:/drustvozadtkb.org/projekti/diple-org-2013/ (pristupljeno 20. V. 2021).

14 Marić 2020: 43-47.

${ }^{15} \mathrm{http}$ //diple.org/index.php/hr/popisi-enkb/115-popis-enkb-za-podrucje-zzh (pristupljeno $20 . \mathrm{V}$. 2021).

${ }^{16}$ www.tkanica.org (pristupljeno 20. V. 2021).

${ }^{17}$ http://drustvozadtkb.org/projekti/tkanica-org-2018/ (pristupljeno 20. V. 2021).

${ }^{18} \mathrm{https}$ //ich.unesco.org/en/living-heritage-experience-and-covid-19-pandemic-01124? id=00257; (pristupljeno 20. V. 2021). 
Aktivnosti Društva za DTKB na izgradnji portala diple.org i tkanica.org do sada su naišli na podršku od Grada Širokog Brijega ${ }^{19}$ Ministarstva obrazovanja, znanosti, kulture i športa Županije Zapadnohercegovačke, ${ }^{20}$ Ministarstva kulture i športa Federacije Bosne i Hercegovine, Ministarstva civilnih poslova Bosne i Hercegovine te Središnjega državnog ureda za Hrvate izvan Republike Hrvatske, a sam UNESCO ih je na svojim službenim Internetskim stranicama prikazao kao pozitivne primjere očuvanja kulturne baštine. ${ }^{21,22}$

\section{Logička struktura baze podataka i metodologija rada}

\subsection{Razrada koncepta}

Prikupljanje, obrada, digitalizacija i prezentacija podataka o elementima nematerijalne kulturne baštine organizacijski je složen posao koji zahtijeva kompleksnu tehničku infrastrukturu. Za njegovo pokretanje bilo je neophodno formirati multidisciplinarni tim za analizu važnijih aspekata realizacije projekta i definiranje osnovnih postavki. Stručnjaci Društva za DTKB u suradnji s partnerima odradili su ovaj posao. Tematika je razložena s gledišta logičke strukture baza podataka, metodologije rada i tehnološke infrastrukture podrške aktivnostima. ${ }^{23}$

Logička struktura baze podataka podrazumijeva preciziranje osnovnih objekata (entiteta) obrade o kojima će se prikupljati informacije i podataka koji će se o njima obrađivati. Metodologija rada podrazumijeva preciziranje aktivnosti koje će se provoditi i njihove izvršitelje. Tehnološka infrastruktura podrške aktivnostima u ovom slučaju podrazumijeva izbor tehničkih platformi i principa njihova korištenja. U nastavku su obrađena prva dva aspekta. Detaljniji opis trećega aspekta tematski spada u usko područje računalnih tehnologija, zbog čega nije posebno razmatran u ovom radu.

${ }^{19}$ http://www.sirokibrijeg.ba/index.php/vijesti/1482-odrzan-znanstveno-strucni-skupa-vrilatradicijskog-naslijeda (pristupljeno 20. V. 2021).

${ }^{20}$ https://mozks-zzh.com/2019/10/28/strucni-skup-o-ocuvanju-elemenata-nematerijalne-kulturne-bastine/ (pristupljeno 20. V. 2021).

${ }^{21}$ https://ich.unesco.org/en/living-heritage-experience-and-covid-19-pandemic-01124?id=00257 (pristupljeno 20. V. 2021).

${ }^{22}$ https://ich.unesco.org/en/living-heritage-experience-and-covid-19-pandemic-01124?id=00380; (pristupljeno 20. V. 2021).

${ }^{23}$ Marić, Ivić, Miloš, Raič 2020: 247-283. 
Razrada koncepta prilagođena je tradicijskoj kulturnoj baštini koja se viđa u svakodnevici lokalnih zajednica ili na festivalima folklora s višegodišnjom tradicijom. U nastavku je opisana logička struktura baze podataka i metodologija rada.

\subsection{Logička struktura baze podataka}

Logička struktura baze podataka podrazumijeva preciziranje osnovnih objekata ili entiteta obrade o kojima će se prikupljati informacije, opis podataka koji će se o njima obrađivati i relacija između pojedinih objekata. Precizirana su četiri osnovna objekta obrade: element NKB-a, baštinik elementa NKB-a, događanje ili festival folklora na kojemu se prezentiraju elementi NKB-a i organizator događanja ili festivala folklora. Definirani objekti omogućavaju cjelovit segmentirani pristup obradi i digitalizaciji materijala o NKB-u u lokalnim zajednicama, što je grafički predstavljeno na slici $1 .{ }^{24}$

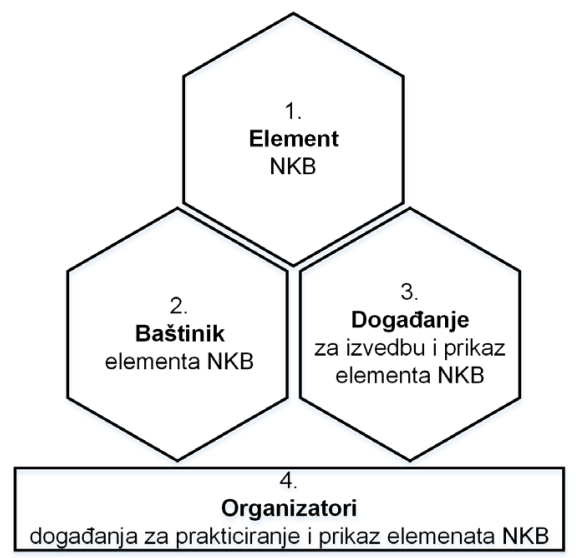

Slika 1. Segmentirani pristup obradi i digitalizaciji materijala o NKB-u

Osnovni podatci koji se obrađuju o elementima NKB-a njegov su naziv, kategorija, lokaliteti za koje je vezan, popis baštinika, broj baštinika, prigoda kad se prakticira, vrijeme u godini kad se prakticira, kratki tekstualni opisi, slikovni zapisi, video i audiozapisi, lokalitet gdje se može vidjeti i vrijeme kad se može vidjeti. Kad je jedan element NKB-a prisutan u više lokalnih zajednica pod različitim imenima, onda se sva ona nastoje pribilježiti. Elementi NKB-a u suradnji s baštinicima kategorizirani su kao tradicijski plesovi, tradicijska pjevanja, vještina sviranja na tradicijskim instrumentima, tradicijski običaji i prakse, stare priče i legende, tradicijske obljetnice i proslave, stari zanati i posebne vještine, tradicijski načini pripremanja hrane u posebnim prigodama i lokalni govor.

\footnotetext{
${ }^{24}$ Isto.
} 
Baštinici elemenata NKB-a u našem su slučaju uglavnom KUD-ovi ili njihovi pojedinačni članovi. Osnovni podatci koji se obrađuju o njima su naziv, lokalitet za koji su vezani, popis svih elemenata koje baštine, aktivnosti koje poduzimaju na prezentaciji elemenata, aktivnosti koje poduzimaju na prenošenju elemenata na mlade naraštaje, kratki tekstualni opisi rada, video i audiozapisi, slikovni zapisi te kontakt podatci.

Festivali folklora u našem su slučaju uglavnom mjesta gdje se elementi NKB-a prezentiraju. Osnovni podatci koji se o njima obrađuju jesu naziv, lokacija održavanja, vrijeme održavanja, organizator, programsko usmjerenje, popisi izvođača u proteklom razdoblju, popis elemenata NKB-a koji se na njima redovito prezentiraju, popratni sadržaji kao i kratki tekstualni opisi posebnosti.

Organizatori festivala folklora omogućavaju širokoj javnosti uvid u rad baštinika, a samim time i prezentaciju elemenata NKB-a. Organizatori folklora uglavnom su pravne osobe. Osnovni podatci koji se obrađuju o njima jesu njihov naziv, sjedište, kontakt podatci, važnije reference. Vrlo se često kao organizatori pojavljuju i KUD-ovi.

Relacije između definiranih objekata obrade objašnjene su u nastavku. Element NKB-a vezan je za određeni lokalitet i ima svoje baštinike. Baštinici elementa NKB-a redovito se predstavljaju na festivalima folklora ili sličnim događanjima. Festivali folklora imaju svoje organizatore koji ih nastoje približiti javnosti. Naglasak je stavljen na same elemente NKB-a. Opisani element NKB-a stavlja se u korelaciju s radom i djelovanjem njegovih baštinika te se redovito tijekom godine predstavlja na određenom festivalu, čime se pruža informacija gdje će i kad biti predstavljen.

\subsection{Metodologija rada}

Prije početka konkretnih aktivnosti bilo je potrebno definirati metodologiju rada, koja podrazumijeva način prikupljanja, obrade, digitalizacije i prezentacije podataka. Sudionici i koraci obuhvaćeni definiranom metodologijom grafički su predstavljeni na slici $2 .{ }^{25}$ Za svakoga od sudionika definirani su koraci, odnosno aktivnosti koje provodi.

Sudionici postupka tehnički su stručnjaci, baštinici, sakupljači na terenu, stručnjaci za pojedine segmente elemenata NKB-a i zainteresirana javnost. $\mathrm{O}$ infrastrukturi sustava brinu tehnički stručnjaci. U suradnji s baštinicima sakupljači prikupljaju materijale o elementima NKB-a na terenu i rade njihovu predobradu. Sakupljači su članovi Društva za DTKB i partnerskih organizacija. Prikupljeni materijali dopunjavaju se informacijama koje pružaju stručnjaci vezani uz pojedini segment tradi-

25 Isto. 


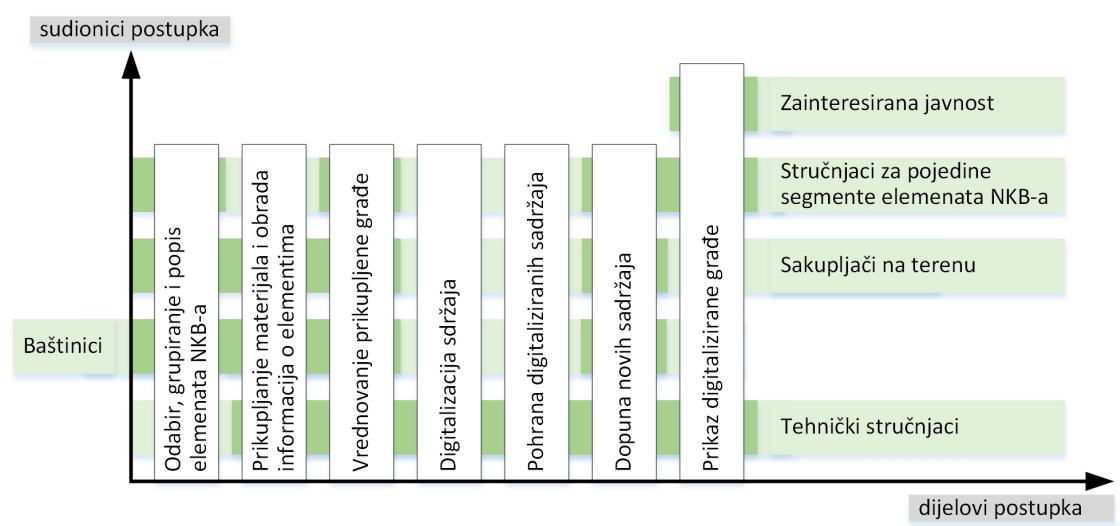

Slika 2. Koraci i sudionici postupka digitalizacije NKB-a

cijske kulturne baštine. Nakon digitalizacije i prilagodbe za internetsku mrežnu prezentaciju omogućava se vidljivost materijala zainteresiranoj javnosti.

Proces započinje izradom taksativnoga popisa elemenata NKB-a, grupiranih po kategorijama koje baštine članovi jednoga KUD-a. Iz popisa se, u suradnji sa samim baštinicima, izdvajaju pojedinačni elementi NKB-a o kojima se prikupljaju materijali i radi obrada podataka. Obrađeni materijali dopunjuju se u suradnji sa stručnjacima za pojedina područja. Dopunjeni materijali prebacuju se u odgovarajuću digitalnu formu. Digitalni sadržaji pohranjuju se na lokalne memorijske medije i multimedijalne baze podataka. Nastojanje je digitalizirane materijale kontinuirano dopunjavati novim sadržajima koji se prezentiraju na festivalima folklora ili sličnim događanjima. Zainteresirana javnost ima mogućnost uvida u digitalnu prezentaciju obrađenih materijala o elementima NKB-a na mrežnim portalima diple.org i tkanica.org. U projektu se koristi velik broj digitalnih zapisa spremljenih na različite memorijske medije. Za realizaciju su također potrebni i resursi klijentske opreme za digitalizaciju i poslužiteljske mrežne internetske infrastrukture za čije je učinkovito korištenje potrebno postaviti sustav upravljanja tehničkim resursima.

Kontinuirano se nastoji u procesu zadržati baštinike kako bi se materijali o elementima NKB-a koje oni baštine mogli neprekidno dopunjavati. Zainteresiranoj se javnosti na ovaj način blagovremeno mogu pružati informacije gdje se i kada pojedini element prezentira, gdje se prakticira, kao i što se sve poduzima za njihovo prenošenje na nove mlade naraštaje. Neprekidnom uključenošću baštinika u proces omogućuje se da pojedini element NKB-a kontinuirano živi u lokalnoj zajednici kao dio njezine pozitivne prepoznatljivosti.

Definirana metodologija rada daje poseban doprinos provedbi UNESCO-ove Konvencije o zaštiti nematerijalne kulturne baštine iz 2003. godine na polju prepoznavanja, vrednovanja i mapiranja elemenata NKB-a. 


\section{Sudionici projekta}

\subsection{Sudionici projekta i raspodjela aktivnosti}

Nositelj realizacije projekata diple.org i tkanica.org jest Društvo za DTKB. U aktivnostima Društva za DTKB naglasak je stavljen na osiguranje tehnološke infrastrukture, digitalizaciju podataka i internetsku prezentaciju obrađenih materijala.

Partneri u realizaciji projekata krovne su udruge KUD-ova u BiH, i to UHAKUD u BiH i Sekcija CIOFF®-a za BiH, kao i njihovi članovi, koji su ujedno i baštinici elemenata NKB-a. Partneri sudjeluju u planiranju aktivnosti, kao i u prikupljanju materijala na terenu i kasnijoj dopuni kako bi se dobila cjelovita slika o elementu NKB-a.

Kad je Društvo za DTKB namjeravalo krenuti s projektom diple.org 2010. godine, UHAKUD u BiH bio je najorganiziranija krovna udruga folkloraša u $\mathrm{BiH}$ s izgrađenim kapacitetima potrebnima za uključivanje u aktivnosti. Pripreme za projekt tkanica.org Društvo za DTKB započinje 2017. godine, i u to je vrijeme u $\mathrm{BiH}$ Sekcija $\mathrm{CIOFF}{ }^{\circledR}$-a za $\mathrm{BiH}$ imala potrebne kapacitete za uključivanje u projekt.

\subsection{Društvo za DTKB}

Nositelj je realizacije projekata diple.org i tkanica.org Društvo za digitalizaciju tradicijske kulturne baštine ili skraćeno Društvo za DTKB. Osnovano je 2008. godine na inicijativu članova UHAKUD-a u BiH kako bi se prikupljanju, obradi, digitalizaciji i kasnijoj prezentaciji materijala o tradicijskoj kulturnoj baštini posvetilo više pozornosti. Sjedište ima u Širokom Brijegu. Član je UHAKUD-a u $\mathrm{BiH}^{26}$ i Sekcije CIOFF®-a za BiH. ${ }^{27}$ Predsjednik je Društva za DTKB u vrijeme pisanja ovoga rada 2021. godine Toni Marić. Na slici 3. nalazi se logo Društva za DTKB. Članovi Društva za DTKB objavili su više stručnih radova o metodologijama prikupljanja, obrade, digitalizacije i promocije materijala o tradicijskoj kulturnoj baštini. ${ }^{28,29,30}$

Društvo za DTKB tijekom godine redovito provodi više projekata: 1. prikupljanje, obrada i dopuna podataka na internetskom portalu diple.org, koji se provodi u

${ }^{26}$ Vladić-Mandarić, Miloš, Vidović 2020: 15-35.

${ }^{27} \mathrm{CIOFF}{ }^{\circledR} \mathrm{BiH}$ (2020). 10 godina s vama CIOFF®, Mostar, USOFFTU u BiH/ Sekcija CIOFF ${ }^{\circledR}$ za BiH.

\footnotetext{
${ }^{28}$ Marić 2020: 43-47.

${ }^{29}$ Marić, Ostojić, Marić 2010: 120-123.

${ }^{30}$ Marić 2008: 157-159.
} 
suradnji s UHAKUD-om u BiH, 2. prikupljanje, obrada i dopuna podataka na internetskom portalu tkanica.org, koji se provodi u suradnji sa Sekcijom CIOFF®-a za $\mathrm{BiH}$, 3. suorganizacija festivala folklora Sveti Ante čuvaj Vrila naša u Dobriču u Širokom Brijegu, 4. organizacija znanstveno-stručnoga skupa na temu očuvanja i digitalizacije materijala o tradicijskoj kulturnoj baštini.

Društvo za DTKB organiziralo je Znanstveno-stručni skup Vrila tradicijskog naslijeđa 2017. godine u Širokom Brijegu koji je za temu imao povijesno, kulturno i prirodno naslijeđe širokobrijeških sela Župe Mostarski Gradac. Dvije godine poslije, 2019., organiziran je Stručni skup o očuvanju elemenata nematerijalne kulturne baštine u Širokom Brijegu.

Opis nekih projekata Društva za DTKB nalazi se i na službenim mrežnim stranicama UNESCO-a. ${ }^{31,32}$

Društvo za DTKB u dosadašnjem radu podržali su grad Šroki Brijeg, Ministarstvo obrazovanja, znanosti, kulture i športa Županije Zapadnohercegovačke, Federalno ministarstvo kulture i sporta Federacije Bosne i Hercegovine, Ministarstvo civilnih poslova Bosne i Hercegovine te Središnji državni ured za Hrvate izvan Republike Hrvatske.

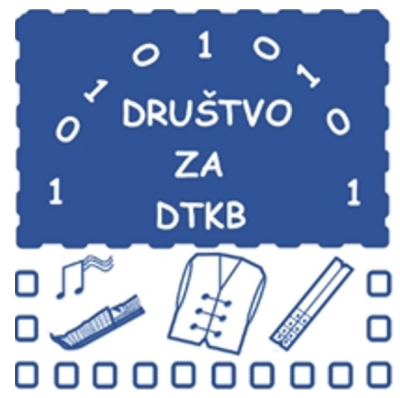

Slika 3. Logo Društva za DTKB

\subsection{Udruga hrvatskih amaterskih kulturno-umjetničkih društava u $\mathrm{BiH}$}

Udruga hrvatskih amaterskih kulturno-umjetničkih društava u $\mathrm{BiH}$ ili skraćeno UHAKUD u BiH krovna je udruga KUD-ova u BiH koji njeguju tradicijsku kulturnu baštinu Hrvata u BiH. ${ }^{33}$ UHAKUD u BiH ima službeni status pri UNESCO-u

31 https:/drustvozadtkb.org/projekti/vrila-tradicisjkog-naslijeda-2017-siroki-brijeg-znanstvenostrucni-skup/ (pristupljeno 20. V. 2021).

32 https://ich.unesco.org/en/living-heritage-experience-and-covid-19-pandemic-01124?id=00257 (pristupljeno 20. V. 2021).

${ }^{33}$ http://uhakud.info/ (pristupljeno 20. V. 2021). 
na području očuvanja nematerijalne kulturne baštine. Broji približno trideset članova, a u svojim programima okuplja više od sto udruga i KUD-ova iz $\mathrm{BiH} .{ }^{34,35,36}$ Osnovan je 2000. godine. Predsjednik UHAKUD-a u BiH u vrijeme pisanja ovoga rada 2021. bio je Vedran Vidović. Na slici 4. nalazi se logo UHAKUD-a u BiH.

Tijekom godine UHAKUD u BiH redovito provodi nekoliko projekata: 1. Državna smotra izvornog folklora Hrvata u $\mathrm{BiH}$, koja se organizira u svibnju u Mostaru i na njoj se predstavljaju elementi NKB-a koje baštine članovi UHAKUD-a u $\mathrm{BiH}, 2$. Seminar Folklora Hrvata u $\mathrm{BiH}$, koji se organizira krajem srpnja ili početkom kolovoza i omogućava stručnu izobrazbu članovima i partnerskim organizacijama, 3. Susreti zborova, koji se organizira na jesen i okuplja svake godine desetak zborova iz $\mathrm{BiH}, 4$. Koordinacija rada članova i slanje KUD-ova na festivale izvan granica $\mathrm{BiH}$ koje organiziraju partnerske udruge i institucije.

UHAKUD u BiH 2020. godine izdao je Zbornik radova predavača sa seminara folklora Hrvata u BiH.
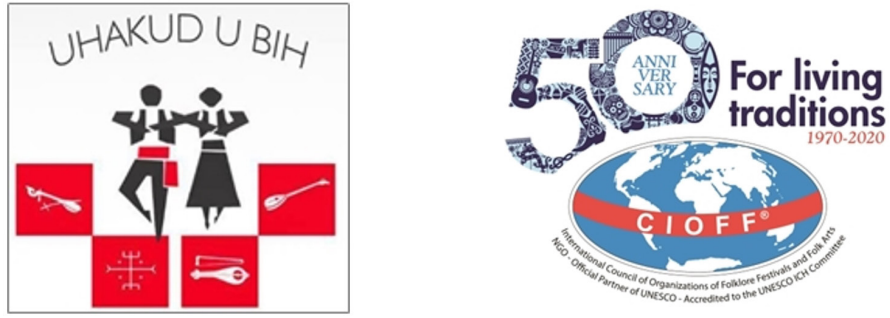

Slika 4. Logo UHAKUD-a u BiH i međunarodnoga CIOFF®-a

\subsection{Sekcija $\mathrm{CIOFF} 囚-\mathrm{a}$ za $\mathrm{BiH}$}

Sekcija CIOFF®-a za BiH akreditirani je partner UNESCO-a za nematerijalnu kulturnu baštinu i dio je međunarodne CIOFF® mreže sa sjedištem u Parizu. ${ }^{37,38,39}$ Ima oko trideset članova, uglavnom KUD-ova. Registrirana je 2010. godine, a predsjednica je Sekcije CIOFF®-a za BiH u vrijeme pisanja ovoga rada 2021. bila Anka Raič. Na slici 4. prikazan je logo međunarodnoga CIOFF®-a.

\footnotetext{
${ }^{34}$ Raič, Anka 2005: 10-12.

35 Vidović 2015: 71-78.

36 Vladić-Mandarić, Miloš, Vidović 2020: 15-35.

${ }^{37} \mathrm{CIOFF}{ }^{\circledR} \mathrm{BiH}$ (2020): 10 godina s vama CIOFF®, Mostar, USOFFTU u BiH/ Sekcija CIOFF® za $\mathrm{BiH}$.

38 Raič, Anka 2010: 170-183.

${ }^{39}$ Raič, Anka 2015: 57-70.
} 
Tijekom godine Sekcija $\mathrm{CIOFF}{ }^{\circledR}$-a za $\mathrm{BiH}$ provodi nekoliko projekata: 1. Podrška u organizaciji festivala folklora u $\mathrm{BiH}$ članica $\mathrm{CIOFF} ®$-a i dovođenje inozemnih skupina u $\mathrm{BiH}$, 2. Slanje KUD-ova iz $\mathrm{BiH}$, članica $\mathrm{CIOFF} ®$-a, na međunarodne CIOFF ${ }^{\circledR}$-ove festivale, 3. Organizacija godišnjeg festivala folklora članica Sekcije CIOFF ${ }^{\circledR}$-a za $\mathrm{BiH}$, 4. Izvještavanje o aktivnostima i promocija članica Sekcije $\mathrm{CIOFF}{ }^{\circledR}-\mathrm{a}$ za $\mathrm{BiH}$ u međunarodnom $\mathrm{CIOFF}{ }^{\circledR}-\mathrm{u}$, 5. Sudjelovanje u radu Godišnjeg svjetskog Kongresa CIOFF®-a i Godišnje sjednice sektora CIOFF®-a za Južnu Europu, 6. Omogućavanje KUD-ovima iz $\mathrm{BiH}$ sudjelovanje na festivalu kulture naroda svijeta u sjedištu UNESCO-a u Parizu kao i u The World Folkloriada svake četiri godine.

Sekcija $\mathrm{CIOFF}{ }^{\circledR}$-a za BiH izdala je 2020. godine brošuru pod nazivom 10 godina s vama $\mathrm{CIOFF}{ }^{\circledR} \mathrm{BiH}$.

Dio projekta Sekcije CIOFF®-a za $\mathrm{BiH}$ opisan je i na službenim mrežnim stranicama UNESCO-a. ${ }^{40}$

\section{Prikaz podataka o KUD-ovima i festivalima folklora na portalu diple.org}

\subsection{Struktura projekta i obujam obrađenih podataka}

Projekt diple.org Društvo za DTKB vodi u suradnji s UHAKUD-om u $\mathrm{BiH}^{41} \mathrm{~s}$ ciljem prezentacije tradicijske kulturne baštine Hrvata u BiH. Prvi materijali na ovom portalu postavljeni su 2013., kada je objavljen popis i osnovni kontakt podatci o KUD-ovima iz $\mathrm{BiH}$ koji u svom radu redovito istražuju, promoviraju i na mlade naraštaje prenose tradicijsku kulturnu baštinu Hrvata iz BiH. Projektom su obuhvaćena 122 KUD-a i 74 festivala folklora ili događanja iz BiH na kojima oni redovito predstavljaju elemente NKB-a koje baštine.

Do početka 2021. godine na ovom portalu dostupni su i dodatno obrađeni materijali o četirima KUD-ovima i trima festivalima koji ih detalinije opisuju u tekstualnoj, slikovnoj, zvučnoj i videoformi. U nastavku je dat prikaz sažetka ovih materijala.

Namjera je u narednom razdoblju obraditi i predstaviti detaljnije podatke i o ostalim KUD-ovima i festivalima koji su prethodno navedeni.

${ }^{40}$ https://drustvozadtkb.org/projekti/vrila-tradicisjkog-naslijeda-2017-siroki-brijeg-znanstvenostrucni-skup/ (pristupljeno 21. II. 2021).

${ }^{41}$ https:/drustvozadtkb.org/projekti/diple-org-2013/ (pristupljeno 20. V. 2021). 


\subsection{Kulturno-umjetnička društva na portalu diple.org}

Projektom diple.org trenutačno su obuhvaćena 122 KUD-a iz BiH koja istražuju, promoviraju i na mlade naraštaje kao baštinike prenose elemente NKB-a koje baštine Hrvati u Bosni i Hercegovini. Napravljeno je i izdanje u pdf formatu pod nazivom Diplar 2013. godine koje je dostupno na ovom portalu. ${ }^{42}$

Na portalu je postavljen i popis $29 \mathrm{KUD}$-ova/udruga s područja Županije Zapadnohercegovačke kao baštinika elemenata NKB-a s ovoga područja. Posebno su obrađeni dodatni materijali o četirima koje su članovi UHAKUD-a u BiH i nastupali su na Državnoj smotri izvornog folklora Hrvata u BiH. To su HKD Vrila iz Širokog Brijega, KUD Mokro iz Širokog Brijega, HKUD Hercegovac iz Širokog Brijega i HKUD Tihaljina iz Tihaljine iz Gruda i o njima su dostupni kratki tekstualni opisi, fotografije i videozapisi s nastupa.

U nastavku je naveden popis po gradovima/općinama 29 KUD-ova/udruga kao baštinika s područja Županije Zapadnohercegovačke koji se nalaze u bazi Društva za DTKB. Neki od njih s grupama mladih naraštaja redovito rade i po dva do tri puta tjedno dok se drugi sastaju jednom mjesečno.

Na području Širokoga Brijega velik dio baštinika elemenata NKB-a djeluje u okrilju 15 KUD-ova/udruga: HKD-a Vrila, HKD-a Dobrkovići, HKUD-a Biloševica, HKUD-a Blaćani s Mostarskog Blata - Biograci, HKUD-a Brda Izbično, HKUD-a Crnač, HKUD-a Crnašnica Knešpolje, HKUD-a Hercegovac, HKUD-a Jare, HKUD-a Kočerin, HKUD-a Sv. Ana Ljuti Dolac, HKUD-a Uzarići, KUD-a Mokro, KUD-a Ganga i Društva Kapina.

Na području Ljubuškoga velik dio baštinika elementa NKB-a djeluje u okrilju šest KUD-ova: HKUD-a Ivan iz Graba, HKUD-a Studenčica iz Studenaca, HKUD-a Klobuk iz Klobuka, HKUD-a Sv. Ante Humac, HKUD-a Antas Mucić Ljubuški i KUD-a Vašarovići.

Na području Gruda znatan broj baštinika elemenata NKB-a djeluje u okrilju pet KUD-ova/udruga: HKUD-a Tihaljina iz Tihaljine, Udruge Davorija, HKUD-a Sveta Kata Grude, HKUD-a Ružići i HKUD-a Sloga Gorice Grude.

Na području Posušja velik dio baštinika elemenata NKB-a djeluje u okrilju triju KUD-ova: HKUD-a Fra Petar Bakula, KŠD-a Rakitno Posušje i HKUD-a Vrisak - Vir.

Hrvatsko kulturno-umjetničko društvo Hercegovac iz Širokog Brijega ili skraćeno HKUD Hercegovac iz Širokog Brijega društvo je Županije

${ }^{42}$ http://diple.org/images/DOWN/DIPLAR-2013-09-30-v401.pdf (pristupljeno 21. II. 2021). 
Zapadnohercegovačke. ${ }^{43,44}$ Osnovano je 1996. godine sa sjedištem u Širokom Brijegu. Ima oko dvije stotine članova organiziranih u više sekcija. U vrijeme izrade ovoga rada predsjednik je HKUD-a Hercegovac bio Jerko Sesar, a umjetnički voditelj Ivan Barać. 45

U nastupima promovira elemente NKB-a iz svoga kraja. U scenskim prikazima redovito su zastupljeni tradicijski plesovi kolanje, biranje, proleta, poskakuša, trusa, dalmatinka, taraban, trojanac. ${ }^{46}$ Nastupaju uz sviranje na tradicijskim glazbalima diplama, svirali ili dvojnici i muziki (usna harmonika). Pjevaju se tradicijske pjesme ganga, bećarac, brojka, putnička pjesma, kolarska pjesma, čobanske pjesme i uspavanke. ${ }^{47}$

HKUD Hercegovac na scenu je postavio više tradicijskih običaja, od kojih se posebno izdvajaju Križanje duvana u Hercegovini, Čuparina vune i Svadbeni običajdolazak mlade.

Društvo organizira Godišnji koncert koji se održava u drugoj polovici prosinca u Širokom Brijegu, gdje zajedno s gostima prezentira i tradicijsku kulturu koju baštine njegovi članovi i gosti. Pokrenulo je Radionicu narodnih nošnji i rukotvorina kako bi se očuvala i na mlade naraštaje prenijela vještina izrade odjevnih i ukrasnih predmeta od tkanine.

Široki Brijeg obiluje mnoštvom kulturno-prirodnih znamenitosti, od kojih se posebno ističu muzej i galerija u Franjevačkom samostanu u Širokom Brijegu, živopisno vrelo Borak i rijeka Lištica, ostatci brojnih ilirskih građevina kao i veći broj nekropola i pojedinačnih stećaka.

Hrvatsko kulturno društvo Vrila Široki Brijeg ili skraćeno HKD Vrila Široki Brijeg korijene rada vuče od 1950-ih. ${ }^{48,49}$ Nakon stanke u aktivnostima zbog ratnih događanja, rad obnavlja 1999., kada je ponovno registrirano sa sjedištem u mjestu Dobriču. Istražuje i promovira tradicijsku kulturnu baštinu širokobrijeških sela Župe Mostarki Gradac u koju spadaju Dobrič, Donji Gradac, Gornji Gradac, Gostuša, Grabova Graga i Provo. Ima oko sto članova razvrstanih u nekoliko sekcija. U vrijeme izrade ovoga rada 2021. godine predsjednik je bio Vlado Bošnjak, a umjetnički voditelj Vlado Marić. ${ }^{0}$

\footnotetext{
${ }^{43}$ Marić 2019: 47-51.

${ }^{44}$ http://diple.org/index.php/hr/hkud-ovi/ (pristupljeno 20. V. 2021).

${ }^{45}$ http://diple.org/index.php/hr/hkud-ovi/118-hrvatsko-kulturno-umjetnicko-drustvo-hercegovac-iz-sirokog-brijega (pristupljeno 30. V. 2021).

${ }^{46}$ Barać 2020: 105-115.

47 Isto.

${ }^{48}$ Marić 2019: 47-51.

49 http://diple.org/index.php/hr/hkud-ovi/ (pristupljeno 20. V. 2021).

${ }^{50}$ http://diple.org/index.php/hr/hkud-ovi/117-hrvatsko-kulturno-drustvo-vrila-siroki-brijeg (pristupljeno 30. V. 2021).
} 


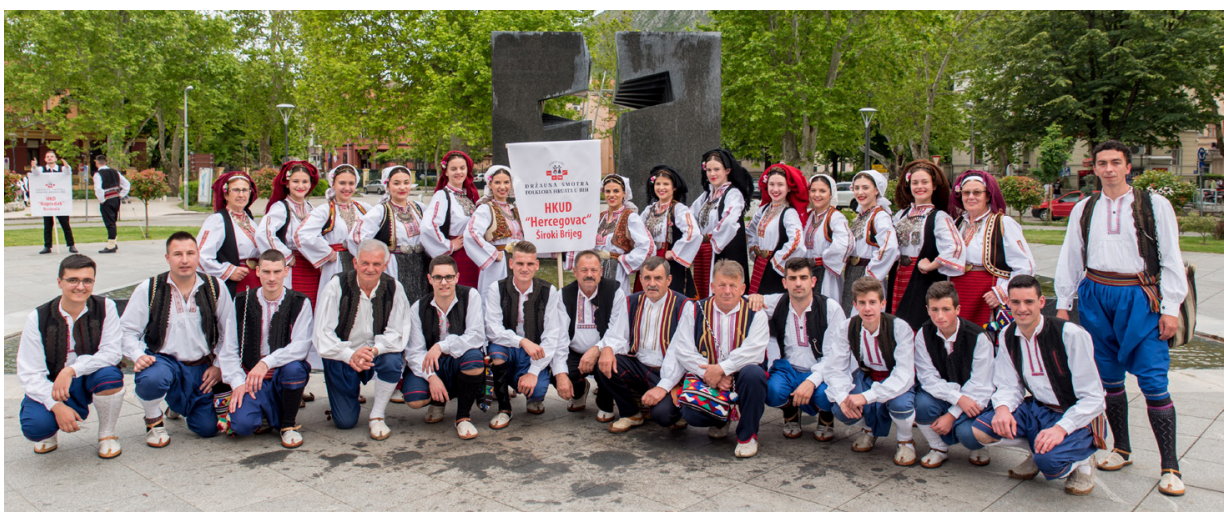

Slika 5. HKUD Hercegovac; Državna smotra izvornog folklora Hrvata u BiH; Mostar; ispred HD-a Herceg Stjepan Kosača; 5/2019.

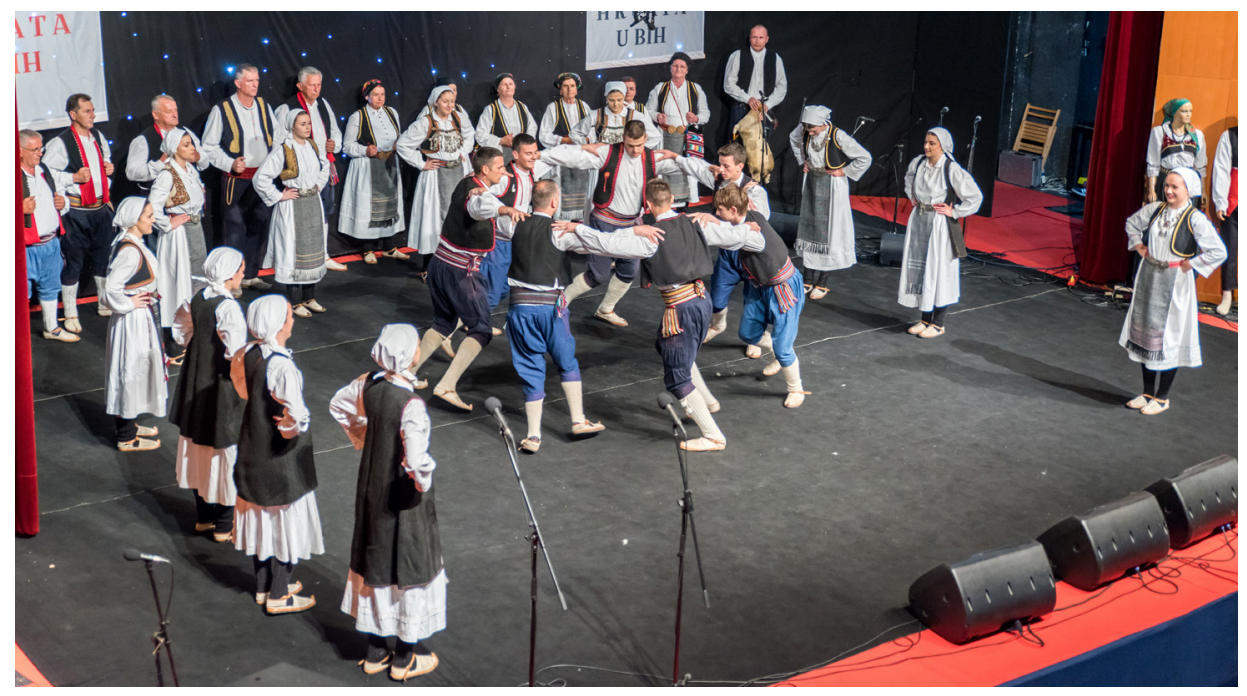

Slika 6. HKD Vrila Široki Brijeg; Državna smotra izvornog folklora Hrvata u BiH; Mostar; pozornica HD-a Herceg Stjepan Kosača; 5/2019.

U nastupima promovira elemente NKB iz svojega kraja. U plesnom dijelu redovito se mogu vidjeti tradicijski plesovi trusa, taraban, bokulja, trojanac, proleta, roma i kolanje. Mogu se čuti tradicijske pjesme ganga, bećarac, putnička pjesma i brojkavica, svatovsko pivanje, čbansko pivanje, kao i sviranje na tradicijskim glazbalima diple, gusle, dvojnica i ćurlik. HKD Vrila na scenu je postavilo više tradicijskih običaja, od kojih se posebno ističu Vučari i Sijelo u Hercegovini.

Navedeni elementi NKB-a redovito se prezentiraju na festivalu folklora Sveti Ante čuvaj Vrila naša u Dobriču u Širokom Brijegu koji se održava svake godine 
početkom lipnja, a koji organizira HKD Vrila s partnerima. Već više od deset godina izdaje kalendar s tradicijskim motivima na kojima se promoviraju pučke proslave na području ovih sela od kojih neke imaju tradiciju dugu gotovo sedam stotina godina.

Kulturno-umjetničko društvo Mokro iz Širokog Brijega ili skraćeno KUD Mokro osnovano je 2000. godine sa sjedištem u mjestu Mokro u Širokom Brijegu. ${ }^{51,52}$ Ima oko sto članova razvrstanih u više sekcija. U vrijeme izrade ovoga rada 2021. godine predsjednica je bila Slavica Ćužić, a umjetnička voditeljica Ana Češkić. ${ }^{33}$ KUD Mokro na javnim nastupima redovito promovira elemente NKB-a svoga kraja. Izvodi tradicijske plesove trusu, taraban, trojanac i kolanje, ukomponirane s tradicijskim pjevanjima gange, bećarca, putničke pjesme, brojkavice, čobanske pjesme i svatovske pjesme. Na nastupima se redovito svira na tradicijskom glazbalu diple i gusle.

Postavili su više običaja na sceni od čega se posebno ističe Kosidba, Običaj prošnje djevojke, Običaj svatova i Običaj cine.

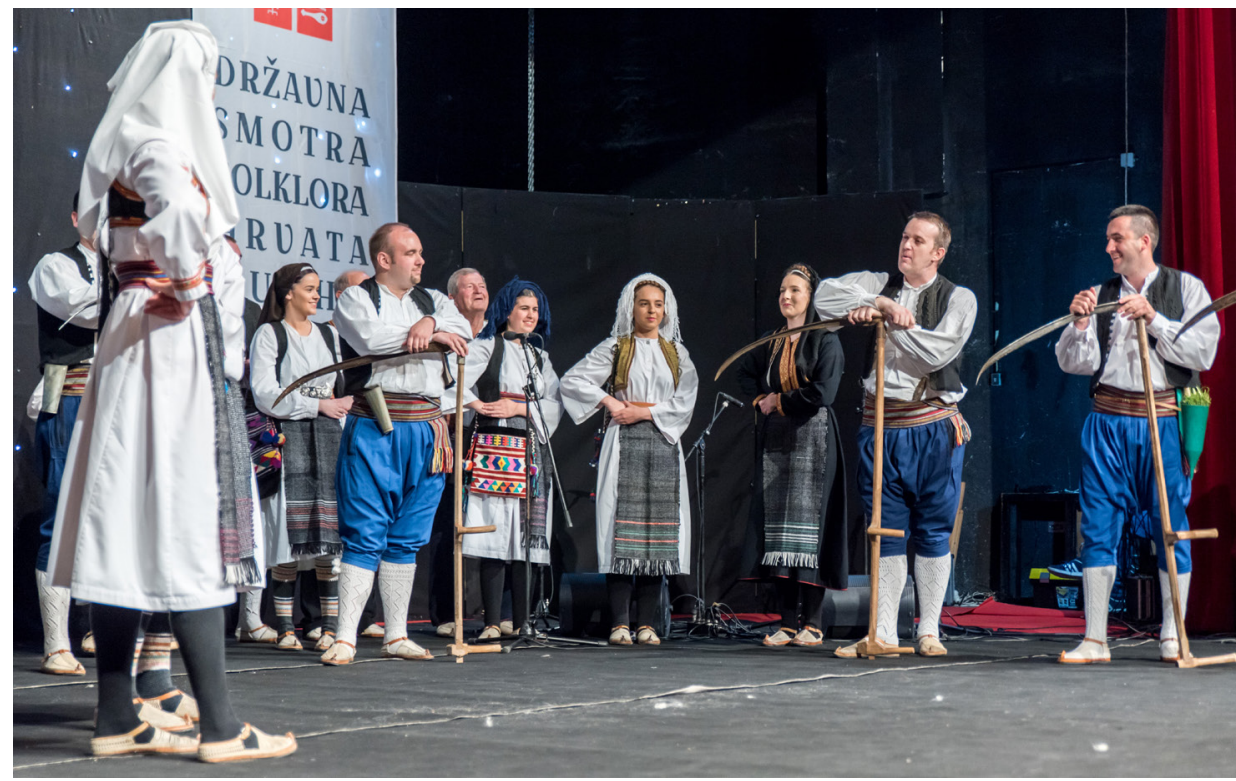

Slika 7. KUD Mokro; Državna smotra izvornog folklora Hrvata u BiH; Mostar; pozornica HD-a Herceg Stjepan Kosača; 5/2019.

${ }^{51}$ Marić 2019: 47-51.

52 http://diple.org/index.php/hr/hkud-ovi/ (pristupljeno 20. V. 2021).

${ }^{53} \mathrm{http}$ //diple.org/index.php/hr/hkud-ovi/120-kulturno-umjetnicko-drustvo-mokro-siroki-brijeg (pristupljeno 30. V. 2021). 
KUD Mokro dugogodišnji je organizator festivala folklora Na temeljima bazilike naše - Mokro koji se održava svake godine u drugoj polovici srpnja. Posvetili su se i istraživanju i promoviranju tradicijskih dječjih igara kao dijela sveukupne kulturne baštine svog kraja. ${ }^{54}$

Mokro ima i bogato materijalno, kulturno i prirodno naslijeđe, od kojih se posebno ističu ostatci ranokršćanske bazilike iz V. ili VI. stoljeća, kao i replika Vitkova stećka. U neposrednoj blizini Mokrog nalazi se muzej i galerija u Franjevačkom samostanu na Širokom Brijegu kao i izvorište Borak.

Hrvatsko kulturno-umjetničko društvo Tihaljina iz Tihaljine iz Gruda ili skraćeno HKUD Tihaljina iz Tihaljine iz Gruda osnovano je 2011. godine sa sjedištem $u$ istoimenom mjestu. ${ }^{55}$ Ima oko šezdeset članova razvrstanih u nekoliko sekcija. U vrijeme izrade ovoga rada 2021. godine predsjednik je HKUD-a Tihaljina bio Ilija Milas, a umjetnički voditelj Ivan Barać. ${ }^{56}$ HKUD Tihaljina redovito promovira tradicijsku kulturnu baštinu svoga kraja. U njihovim nastupima posebno su zastupljeni kao elementi NKB-a tradicijski plesovi trusa, taraban, trojanac i kolanje. Na nastupima promoviraju i tradicijska pjevanja gangu, bećarac, putničku pjesmu, svatovske pjesme i čobanske pjesme. Od tradicijskih glazbala, njeguju sviranje na diplama i sviranje i pjevanje uz gusle. Na scenu su postavili više običaja, od kojih posebno ističu Listanje i priprema duvana za vaganje i Čupanje, predenje i pletenje vune. Organizatori su festivala folklora Tialjsko silo koji se održava 20. srpnja svake godine, po-

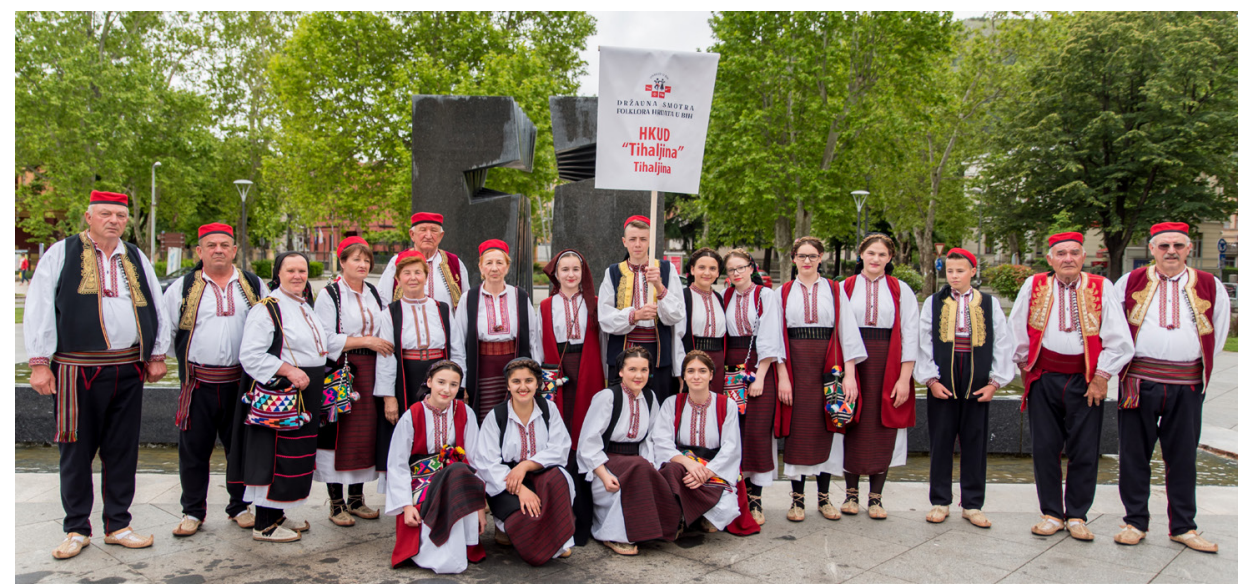

Slika 8. HKUD Tihaljina; Državna smotra izvornog folklora Hrvata u BiH; Mostar; ispred HD-a Herceg Stjepan Kosača; 5/2019.

\footnotetext{
54 Češkić 2020: 117-136.

55 http://diple.org/index.php/hr/hkud-ovi/ (pristupljeno 20. V. 2021).

${ }^{56}$ http://diple.org/index.php/hr/hkud-ovi/119-hrvatsko-kulturno-umjetnicko-drustvo-tihaljina-iz-tihaljine (pristupljeno 30. V. 2021).
} 
čevši od 2011. Festival ima međunarodni karakter i na njemu se svake godine predstave izvođači iz više različitih država. Mjesto Tihaljina ima bogatu kulturnu, povijesnu i prirodnu baštinu. Posebno se ističu nadaleko poznata Ravlića pećina, izvor rijeke Tihaljine kao i Avanturistički park Peć Mlini.

Društvo za DTKB namjerava u narednom periodu obraditi detalinije materijale i o ostalim KUD-ovima koji su prethodno navedeni.

\subsection{Festivali folklora na portalu diple.org}

Projektom diple.org trenutačno su obuhvaćena tri festivala folklora: Državna smotra izvornog folklora Hrvata u BiH - Mostar, Sveti Ante čuvaj Vrila naša - Dobrič - Široki Brijeg i Božićno silo u Grudama ${ }^{57}$ Na svakom od ovih festivala predstavljaju se i baštinici iz mjesta održavanja festivala uz predstavljanje elemenata NKB-a svojega kraja.

Državna smotra izvornog folklora Hrvata u BiH već duži niz godina održava se u Mostaru u prvoj polovici svibnja u organizaciji UHAKUD-a u BiH.58 Suorganizator je smotre i Hrvatska kulturna zajednica u FBiH. Ovaj festival ima tradiciju dužu od dvadeset godina. Na festivalu održanom 2019. godine na sceni su se predstavili: HKUD Zora Struge - Gorica iz Čaplijne, HKUD Tamburica Koraće iz Bosanskog Broda (s plesovima Hrvata Bosanske Posavine), HKUD Rodoč iz Mostara, HKUD Gromovnik iz Novog Šehera iz Maglaja, HKUD Luke Višići iz Čapljine, HKUD Goranci iz Mostara, HKUD Gromiljak iz Kiseljaka, HKUD Tihaljina iz Tihaljine iz Gruda, KUD Rudine župa Vidoši iz Livna, HKUD Hercegovac iz Širokog Brijega, HKD Napredak podružnica Busovača, KUD Mokro iz Širokog Brijega, HKUD Vrila iz Širokog Brijega i KU Linđo Ošlje-Stupa iz Dubrovnika.

$\mathrm{Na}$ portalu diple.org nalaze se fotografije i kratki videozapisi dijela nastupa svakoga izvođača.

Više podataka o ovom festivalu može se naći na stranicama organizatora UHAKUD-a u BiH na internetskoj domeni uhakud.info i stranicama suorganizatora Hrvatske kulturne zajednice u FBiH na internetskoj domeni hkzufbih.org.

Festival folklora pod nazivom Večer folklora Sveti Ante čuvaj Vrila naša održava se početkom lipnja u mjestu Dobriču, u Širokom Brijegu, u organizaciji HKD-a Vrila i partnera. ${ }^{59,60} \mathrm{Na}$ festivalu, koji je održan 8. lipnja 2019., predstavili su

\footnotetext{
${ }^{57}$ http://diple.org/index.php/hr/festivali-folklora (pristupljeno 20. V. 2021).

${ }^{58}$ Isto.

${ }^{59}$ Marić, Bošnjak, Marić 2017: 32-35.

${ }^{60} \mathrm{http}$ ://diple.org/index.php/hr/festivali-folklora (pristupljeno 20. V. 2021.).
} 
se izvođači: HKD Vrila Široki Brijeg, HKD Mokro iz Širokog Brijega, HKUD Herceg Stjepan Buna iz Mostara, KUD Srce Zagore iz Kaštela iz Hrvatske, vokalna etno skupina Sinovi Hercegovine iz Širokog Brijega i diplar Stole Damjanović iz Biograca iz Šrokog Brijega.

Područje Dobriča i ostalih sela širokobriješke Župe Mostarski Gradac ${ }^{61}$ bogato je kulturnim, povijesnim i prirodnim naslijeđem, u koje se ubrajaju velik broj gradina, gomila, zidina, stećaka, vrela, starih bunara, staroga »rimskog« mosta, kanjona Baćine, izletničke staze i vidikovac Kapina, krda konja, malih endemskih riba prikanaca i raznih drugih. U neposrednoj blizini na lokaciji Varda u mjestu Knešpolje nalazi se i velika nekropola stećaka i ostatci srednjovjekovne crkve. ${ }^{62}$

Božićno silo u Grudama održava se svake godine krajem prosinca u organizaciji Udruge Davorija iz Gruda. Materijale za portal diple.org osigurao je organizator. ${ }^{63} \mathrm{Na}$ ovom festivalu redovito se predstavljaju različiti oblici tradicijskoga pjevanja gange kao i sviranja na tradicijskim glazbalima diplama i guslama.

Festival je održan 21. prosinca 2019. godine pod nazivom VIII. Božićno silo Grude. Imao je međunarodni karakter jer je na njemu nastupilo devetnaest izvođača iz triju država ${ }^{64,65}$ : guslar Jure Miloš iz Gruda; gangaška skupina iz Gruda i Imotskog iz Hrvatske u sastavu Milan Škoro, Stjepan Jelić i Krešimir Bušić; gangaška skupina iz Gruda Jure Miloš, Ivan Alpeza i Vinko Alpeza; narodni guslar Stevan Mišo Popović iz Nikšića iz Crne Gore; gangaška skupina iz Posušja Ante Grubišić, Josip Bašić, Tomislav Kovač i Jure Begić; gangaška skupina iz Gruda i Širokog Brijega Vinko Alpeza, Blago Karačić, Ivan Grubišić i Grgo Bondža; guslar Ilija Proleta iz Stoca; ženska gangaška skupina iz Posušja i Tomislavgrada Nada Jukić, Anđa Markić, Ruža Bagarić, Celija Mašić i Luca Matić; diplar Nediliko Madžar iz Drniša iz Hrvatske, ženska gangaška skupina iz Gruda Drina Sesar, Snježana Grizelj, Anđa Prlić, Lenka Prlić; narodni guslar Milan Vujović iz Nikšića iz Crne Gore; gangaška skupina iz Gruda Mate Tolić, Jure Miloš i Mile Čale; gangaška skupina iz Gruda Mile Sesar, Mile Prlić, Srećko Spajić, Ante Boban, Smiljan Glavaš; guslar Mate Grubišić iz Posušja; gangaška skupina iz Gruda Ivan Ćorluka, Jure Ćorluka, Petar Miloš; gangaška skupina iz Posušja Ante Grubišić, Josip Bašić, Tomislav Kovač, Jozo Penava; narodni guslar Kosta Plakalović iz Vučje Luke iz Crne Gore; gangaška skupina

\footnotetext{
61 Rotim 1995.

62 Soldo 2015: 11-25.

${ }^{63}$ http://diple.org/index.php/hr/festivali-folklora (pristupljeno 20. V. 2021).

${ }^{64}$ https://udruga-davorija.com/bozicno-silo-2019/ (pristupljeno 30. V. 2021).

${ }^{65} \mathrm{http} / /$ diple.org/index.php/hr/festivali-folklora/84-bozicno-silo-u-grudama (pristupljeno $30 . \mathrm{V}$.
} 2021). 
iz Gruda i Posušja Stjepan Jelić, Jure Begić; gangaška skupina iz Gruda Stjepan Jelić, Goran Marić i Damir Miloš.

Ovaj festival kod posjetitelja i šire javnosti prepoznat je kao mjesto na kojem se među ostalim redovito prezentiraju dva elementa NKB-a, i to raznovrsne izvedbe tradicijske pjesme gange kao i sviranja i pjevanja uz tradicijski instrument gusle.

Grude obiluju prirodnom, povijesnom i kulturnom baštinom, od koje se posebno ističu ostatci ranokršćanske crkve i muzej u Gorici, kao i Avanturistički park Peć Mlini.

Na portalu diple.org nalaze se fotografije i kratak videoisječak nastupa svakoga izvođača.

Organizator festivala 2021. godine postavio je dio materijala i na svojoj mrežnoj stranici na domeni udruga-davorija.com ${ }^{66}$ na kojoj se nalazi više informacija o festivalu i aktivnostima Udruge Davorija.

Društvo za DTKB u svojoj bazi ima 74 festivala folklora u $\mathrm{BiH}$ na kojima se redovito prezentira i tradicijska kulturna baština Hrvata. Namjera je u narednom razdoblju i ostale festivale, uz ova tri navedena, detaljnije obraditi i prezentirati.

\section{Prikaz popisa nekih od karakterističnih elemenata NKB-a na portalu diple.org}

\subsection{Izbor lokaliteta}

Na portalu diple.org postavljena su dva popisa nekih od karakterističnih elemenata NKB-a za dva lokaliteta. ${ }^{67}$ Prvi je popis za mikrolokalitet za područje širokobrijeških sela Župe Mostarski Gradac koja obuhvaća sela Dobrič, Donji Gradac, Gornji Gradac, Gostuša, Grabova Draga i Provo, a drugi je popis za jednu regiju odnosno područje Županije Zapadnohercegovačke. ${ }^{68} \mathrm{U}$ nastavku su prikazani kratki opisi rada na terenu na izradi ovih dvaju popisa kao i sažeti prikazi nekih elemenata NKB-a za područje Županije Zapadnohercegovačke.

Pod pojmom element NKB-a ovdje se smatra dio nematerijalne kulturne baštine koji je još uvijek živ u lokalnoj zajednici, ima svoje baštinike, redovito se prezentira i kontinuirano se provode aktivnosti na njegovu prenošenju na mlade naraštaje.

\footnotetext{
${ }^{66}$ https://udruga-davorija.com/ (pristupljeno 20. V. 2021).

${ }^{67} \mathrm{http}$ ://diple.org/index.php/hr/popisi-enkb (pristupljeno 20. V. 2021).

${ }^{68} \mathrm{http}$ //diple.org/index.php/hr/popisi-enkb/115-popis-enkb-za-podrucje-zzh (pristupljeno $20 . \mathrm{V}$.
} 2021). 
Različiti popisi elemenata NKB-a s kratkim opisima na portalu diple.org nisu službene liste, već služe kao informacija široj javnosti i moguća pomoć institucijama koje u svojim ovlastima imaju izradu službenih listi elemenata NKB-a kako to predviđa konvencija UNESCO-a iz 2003. godine i zakonska regulativa u $\mathrm{BiH}$.

\subsection{Rad na terenu na području širokobrijeških sela Župe Mostarski Gradac}

Izradi popisa nekih od elemenata NKB-a za područje širokobrijeških sela Župe Mostarski Gradac prethodilo je održavanje znanstveno-stručnoga skupa u Gornjem Gracu u Širokom Brijegu pod nazivom Vrila tradicijskog naslijeđa 2017.69 Na skupu je izlagalo više istraživača i znanstvenika koji su predstavili kulturnu baštinu ovoga područja iz različitih segmenata. Na osnovi razmatranja i preporuka sa skupa formirana je stručna skupina Društva za DTKB za izradu popisa nekih od elemenata NKB-a ovoga područja. Stručna je skupina u suradnji s članovima HKD-a Vrila i Društva Kapina radila na terenu na području sela Župe Mostarski Gradac, ${ }^{70}$ koja obuhvaća Dobrič, Donji Gradac, Gornji Gradac, Gostušu, Grabovu Dragu i Provo. Na terenu su prikupljeni materijali i u kratkim crtama opisano je 57 elemenata NKB-a karakterističnih za ovo područje. Ovaj popis pojednostavljuje stvaranje cjelovite slike NKB-a ovoga kraja. ${ }^{71}$

Elementi su razvrstani po kategorijama kao tradicijski plesovi, tradicijski napjevi ili pjevanja, vještine sviranja na tradicijskim glazbalima, stari tradicijski običaji, tradicijska događanja i pučke proslave, tradicijski načini pripremanja hrane u posebnim prigodama, stari recepti i načini liječenja, tradicijske vještine i zanati, usmena predaja i stare pripovijesti i legende, tradicijski sportovi, tradicijske dječje igre, lokalni jezik i dijalekt. Uz opis elemenata, dat je i kratak prikaz najvažnijih prirodnih odlika ovoga područja, kao i materijalne kulturne baštine koji omogućavaju dobivanje potpunije slike konteksta NKB-a.

Prikupljeni i obrađeni materijali mogu poslužiti i kao pomoć pri izradi službenih popisa elemenata NKB-a. Nastavak ovih aktivnosti ide u smjeru prikupljanja i obrađivanja detaljnije građe o pojedinim elementima NKB-a koji bi se ubuduće upisivali na službene popise.

${ }^{69}$ https://drustvozadtkb.org/projekti/vrila-tradicisjkog-naslijeda-2017-siroki-brijeg-znanstvenostrucni-skup/ (pristupljeno 21. II. 2021).

70 Rotim 1995.

${ }^{71}$ Marić 2020: 43-47. 


\subsection{Rad na terenu na području Županije Zapadnohercegovačke}

Društvo za DTKB organiziralo je u Širokom Brijegu 2019. godine Znanstveno-stručni skup o digitalizaciji i očuvanju elemenata NKB-a, ${ }^{72}$ na kojem su se okupili stručnjaci za NKB, stručnjaci za digitalizaciju, istraživači na terenu, kao i predstavnici više KUD-ova i državnih institucija. Na osnovu izlaganja i preporuka na skupu nastala je inicijativa za izradu popisa jednog broja karakterističnih elemenata NKB-a za područje Županije Zapadnohercegovačke. Tim sačinjen od članova Društva za DTKB, članova UHAKUD-a u BiH i predstavnika KUD-ova s područja županije do izrade ovoga rada, početka 2021. godine, na inicijalnom popisu sažeto je opisao 14 elemenata NKB-a. Popis nije konačan, nego će se i u narednom vremenu dopunjavati. Opisane elemente NKB-a baštini velik dio članova KUD-ova s područja ove županije. Kao i u prethodnom slučaju, ovo nije službeni popis nego može poslužiti u njegovoj izradi.

Elementi NKB-a na ovom popisu grupirani su u pet cjelina. U nastavku su pruženi sažeti opisi pojedinačnih elemenata NKB-a po grupama, koji se nalazi na portalu diple.org. ${ }^{73}$

\subsection{Dio tradicijskih pjevanja na području Županije Zapadnohercegovačke}

Do početka 2021. godine obrađeni su podatci o četirima tradicijskim pjevanjima koja se prakticiraju na području najvećega dijela Županije Zapadnohercegovačke. Tradicijska su pjevanja ganga, Zdravo tilo Isusovo, U sve vrime godišta ili Božićna pjesma i Gospin plač.

\section{1) Ganga}

Ganga se može opisati i kao »baštinjeno višeglasno pučko pjevanje u kojemu jedan glas (pivač) pjeva riječi pismice, a drugi glas (priginjač ili unison od više glasova priginjači) prati pivača priginjajući $(. ..) \ll{ }^{74}$ Ganga je tradicijski izričaj svojstven, najvećim dijelom, Hercegovini i Imotskoj krajini. Pjevaju ga i muškarci i žene u raznim

\footnotetext{
${ }^{72} \mathrm{https} / / / \mathrm{drustvozadtkb} . o r g /$ projekti/strucni-skup-o-ocuvanju-elemenata-nematerijalne-kulturne-bastine-siroki-brijeg-2019/ (pristupljeno 21. II. 2021).

${ }^{73} \mathrm{http} / / /$ diple.org/index.php/hr/popisi-enkb/115-popis-enkb-za-podrucje-zzh (pristuplieno 20. V. 2021).

${ }^{74}$ Kraljević 2017.
} 
prigodama i to, gotovo uvijek, u desetercu. ${ }^{75,76,77,78,79,80}$ Gangu baštine članovi svih KUD-ova s područja Županije Zapadnohercegovačke.

\section{2) Zdravo tilo Isusovo}

Pjesma Zdravo tilo Isusovo tradicijsko je dvoglasno crkveno pjevanje, a ponekad i s povremenim jednoglasjem. Pjevaju ga žene i muškarci prilikom misnoga slavlja, a uglavnom se pjeva u crkvi. Ova pjesma duboko je ukorijenjena među stanovnicima mjesta Županije Zapadnohercegovačke, a i šire, kao dio tradicijske kulturne baštine.

\section{3) U sve vrime godišta}

Pjesma U sve vrime godišta tradicijsko je dvoglasno, a ponekad i s povremenim jednoglasjem, pučko pjevanje. Pjevaju ga žene i muškarci u božićno vrijeme. Tekst pjesme opisuje rođenje Isusa Krista. Pjeva se u obiteljskom domu i u crkvi. U obiteljskom domu obično se u vrijeme pred Božić, u večernjim satima okupe svi članovi i pjevaju ovu pjesmu. Pjesma se pjeva i na sam blagdan Božića najčešće uz božićno žito ukrašeno s tri svijeće u velikom broju obitelji. Kroz pjesmu se slavi i novi život koji dolazi rođenjem. Ova pjesma nerazdvojni je dio tradicijskog kulturnog naslijeđa povezanog s božićnim blagdanima velikog broja stanovnika, kako u ruralnim, tako i u urbanim dijelovima Županije Zapadnohercegovačke, a i šire.

\section{4) Gospin plač}

Pjesma Gospin plač tradicijsko je dvoglasno, a ponekad is povremenim jednoglasjem, pučko pjevanje. Pjevaju ga žene i muškarci za vrijeme korizme odnosno tijekom četrdeset dana prije blagdana Uskrsa. Tekst pjesme opisuje muku Isusa Krista, njegovo razapinjanje i smrt na križu. Pjeva se u kući i u crkvi. U obiteljskom domu obično se $\mathrm{u}$ vrijeme korizme $u$ večernjim satima okupe svi članovi i pjevaju ovu tužnu pjesmu kao podsjetnik na muku i patnju Isusa Krista nakon koje je došlo uskrsnuće. Jedna je od poruka ove pjesme koja se prenosi kroz narod kako dobrota i istina uvijek na kraju pobijede. Postala je sastavni dio tradicijskoga kulturnog naslijeđa velikog broja stanovnika Županije Zapadnohercegovačke.

\footnotetext{
${ }^{75}$ Hrovatin 2015: 14-56.

${ }^{76}$ Kraljević 2017.

${ }^{77}$ Kraljević 2020: 45-61.

${ }^{78}$ Miloš 2015: 79-90.

${ }^{79}$ Miloš 2020: 61-70.

${ }^{80}$ Rihtman 1970: 363-417.
} 


\subsection{Vještine sviranja na tradicijskim glazbalima na području Županije Zapadnohercegovačke}

Na portalu diple.org do početka 2021. godine obrađeni su podatci o vještini sviranja na tri tradicijska glazbala koja se koriste na području Županije Zapadnohercegovačke. To su sviranje $i$ pjevanje uz gusle, sviranje i igranje uz diple, sviranje i igranje uz sviralu ili dvojnice.

\section{1) Sviranje i pjevanje uz gusle}

Gusle su tradicijsko gudačko glazbalo napravljeno od javora, a preko zvučnoga dijela gusala (korito ....) postavljena je koža od jareta. Na krčalo (zatezač, ključ) i oputu (najniži dio zvučnoga dijela gusala) te na gudalo postavljena je struna od dlaka konjskoga repa. Osim javora, jareće kože i konjske dlake rabe se, pogotovo u novije vrijeme, i drugi materijali. Koristi se isključivo kao pratnja uz pjevanje tradicijskih epskih pjesama u desetercu. Na području Županije Zapadnohercegovačke nalazi se veći broj baštinika sviranja i pjevanja uz gusle. ${ }^{81}$

\section{2) Sviranje i igranje uz diple}

Tradicijsko puhačko glazbalo napravljeno od jareće kože, sa sviralom prsnicom od javora s dvije cijevi i dva piska najčešće od trstike. Na koži se nalazi dulac za napuhivanje zraka te vrlo često i ogledalo i zubi od divljega vepra ili rogovi od divokoze. U zadnje vrijeme diple se najčešće koriste kao glazbena pratnja uz ples, ali su se nekada više koristile za solodionice. Sviranje i plesanje uz diple baštine svi KUD-ovi s područja Županije Zapadnohercegovačke. ${ }^{82,83}$

\section{3) Svirala/dvojnice}

Svirala ili dvojnice su tradicijsko puhačko glazbalo pravljeno uglavnom od javora, $\mathrm{s}$ dvije cijevi i dva piska. Koristi se kao pratnja uz ples ili solo dionice. Najčešće su ih izrađivali i koristili pastiri. Korištena je ponekad i na seoskim sijelima i pučkim obljetnicama. Sviranje i plesanje uz sviralu baštine gotovo svi KUD-ovi s područja Županije Zapadnohercegovačke. ${ }^{84,85}$

\footnotetext{
${ }^{81}$ Marić, Ivić, Miloš, Raič 2020: 247-283.

${ }^{82}$ Barać 2020: 105-115.

${ }^{83}$ Marić, Ivić, Miloš, Raič 2020: 247-283.

${ }^{84}$ Barać 2020: 105-115.

${ }^{85}$ Marić, Ivić, Miloš, Raič 2020: 247-283.
} 


\subsection{Dio tradicijskih plesova u Županiji Zapadnohercegovačkoj}

Obrađeni su podatci, do početka 2021. godine, o trima tradicijskim plesovima na području Županije Zapadnohercegovačke koji su još uvijek živi u lokalnim zajednicama. Ti plesovi su trusa, taraban, proleta.

\section{1) Trusa}

Trusa je tradicijski ples koji se pleše u trokoraku punim stopalom. Treći korak često je naglašen jačim udarcem stopala o podlogu. Može se plesati uz pratnju dipala, dvojnica, usne harmonike ili na suvo, bez pratnje glazbala. Pleše se u mjestu ili po kolu u obliku kruga. ${ }^{86,87}$

Kolo se kreće uvijek u lijevu stranu. Pleše se bez pjevanja. Plesači i plesačice izmiješani su i drže se za dlanove. Ovaj tradicijski ples baštine svi KUD-ovi s područja Županije Zapadnohercegovačke.

\section{2) Taraban}

Tradicijski ples tarabana čini cjelina od dva trokoraka i iskorak naprijed desnom ili lijevom nogom ovisno od mikro lokaliteta. Pleše se punim stopalom uz pratnju dipala, dvojnica, usne harmonike ili na suvo. Iskorak nogom naprijed naglašen je jačim udarcem stopala o podlogu. Plešući taraban, kolo se, osim plesa u mjestu, može lagano kretati u lijevu stranu. Pleše se bez pjevanja. Plesači i plesačice izmiješani su i drže se za dlanove. Ovaj tradicijski ples baštine svi KUD-ovi s područja Županije Zapadnohercegovačke. ${ }^{88,89}$

\section{3) Proleta}

Oličenje je dinarskoga područja tradicijski ples proleta. Proletu su plesali mladić i djevojka u zatvorenu kolu. Međusobno se gledaju u oči udaljeni do jedan metar jedno od drugoga. U laganim poskocima s noge na nogu mijenjaju mjesta. Djevojka drži ispružene ruke s dlanovima okrenutim prema tlu, dok mladić drži ruke iznad sebe. U ovome se plesu ogleda otmjenost mladića i djevojke. Ovaj tradicijski ples baštine svi KUD-ovi s područja Županije Zapadnohercegovačke. ${ }^{90}$

\footnotetext{
${ }^{86}$ Barać 2020: 105-115.

${ }^{87}$ Marić, Ivić, Miloš, Raič 2020: 247-283.

${ }^{88}$ Barać 2020: 105-115.

${ }^{89}$ Marić, Ivić, Miloš, Raič 2020: 247-283.

${ }^{90}$ Isto.
} 


\subsection{Dio starih legendi, priča i usmenih predaja u Županiji Zapadnohercegovačkoj}

Na portalu diple.org do početka 2021. godine ukratko su obrađeni podatci o tri usmene predaje koje se još uvijek prepričavaju u mnogim mjestima na području Županije Zapadnohercegovačke. Opisana je Usmena predaja o Bilom lovcu ili Kudi, Usmena predaja o Kučibabi, Usmena predaja o Džudžanu.

\section{1) Usmena predaja o bilom lovcu Kudi}

Usmena predaja o Bilom lovcu ili Kudi po narodnoj predaji govori kako je Bili lovac ili Kudo nekad davno živio na području Hercegovine. ${ }^{91}$ Bio je strastven lovac. U lov je uvijek išao s dva psa. Njegova strast za lovom bila je pretjerana. Druge je ljude ponekad ometao u njihovim svakodnevnim poslovima dok je bio u lovu. Za života je bio proklet zbog pucnjave u blizini crkve i ometanja drugih ljudi dok su bili na misi. Jedna od poruka ove usmene predaje je kako u svemu treba imati mjeru.

Ljudi su pričali kako su nakon njegove smrti često viđali veliku sjenku čovjeka i dvaju pasa kako preskaču s brda na brdo. Govorilo se i kako bi se po mjesečini često čuo i lavež njegovih pasa.

Mještani, ovisno od mjesta do mjesta, navode u svojim prepričavanjima ove legende različitih mjesta u kojima se Kudo navodno rodio i živio. Jedna od interpretacija usmene predaje, koja se prepričava na području širokobrijeških sela Župe Mostarski Gradac, govori da se rodio, živio te je nakon smrti pokopan u Grabovoj Dragi. Pored Marića groblja u Grabovoj Dragi postoje ostatci groba za koji se tvrdi kako je u njega ukopan Kuda. Također, ista priča nastavlja da je nakon smrti viđen kako preskače preko kanjona Baćine iz Pologa u Dobrič i dalje ide prema Grabovoj Dragi.

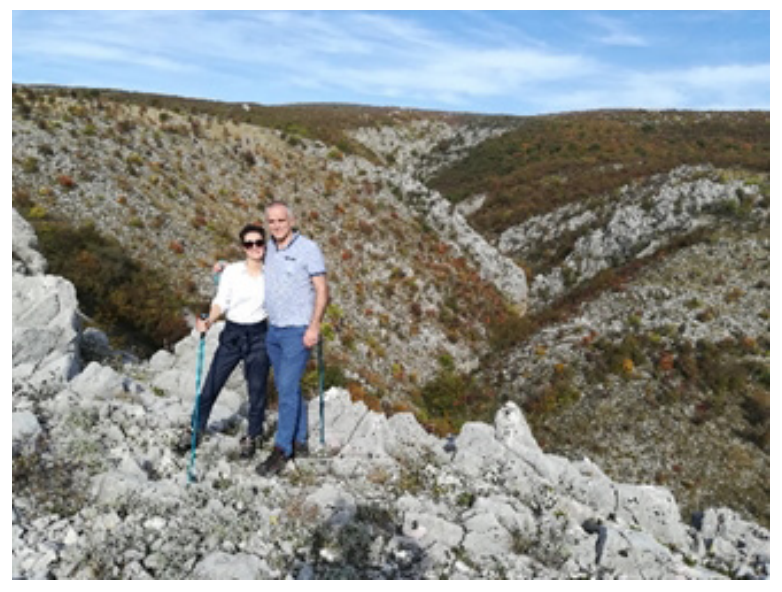

Slika 9. Izletnici na Velikoj gomili iznad Avlija u mjestu Dobriču u Širokom Brijegu 2019. U pozadini je kanjon Baćine, gdje je po narodnoj predaji Bili lovac ili Kudo preskakao s jedne strane kanjona na drugu.

91 Isto. 
Dobrič i Grabova Draga su naseljena mjesta na području Širokog Brijega, a Polog je naseljeno mjesto na području Mostara.

Ovu usmenu predaju prepričava i baštini više mjesta u Županiji Zapadnohercegovačkoj kao dio tradicijske kulturne baštine.

\section{2) Usmena predaja o Kučibabi}

Usmena predaja o Kučibabi nastala je s namjerom da se djecu zaštiti od upadanja u čatrnje. ${ }^{92}$ Po narodnoj predaji u svakoj čatrnji nalazi se strašno stvorenje Kučibaba. ${ }^{93}$ Nitko nikad Kučibabu nije vidio, ali svi pričaju kako je strašna. Malu se djecu plašilo kako ne bi bez odraslih prilazila otvorima na čatrnjama i tako sebe dovodila u opasnost, da u nju upadnu jer prije nije bila krunā - obzida oko otvora čatrnje. Djeci se govorilo ako se tko malen rastom približi vratnicama čatrnje, može iskočiti Kučibaba i povući ga unutra. Legendu o Kučibabi prepričava znatan broj mještana u naseljima Županije Zapadnohercegovačke kao dio tradicijske kulturne baštine.

\section{3) Usmena predaja o Džudžanu}

Usmena predaja o Džudžanu govori kako je $D \check{z} u d \check{a} a n$ mitska životinja, veličine lasice, koja se po narodnoj predaji hrani kokošima i sitnim domaćim životinjama. Zbog toga se djeci govorilo kako se sve sitne domaće životinje moraju prije noći skupiti i zatvoriti u svoje prostorije kako ne bi bez njih ostali jer će ih Džudžan odnijeti. ${ }^{94}$ Legendu baštine mještani većine naselja u Županji Zapadnohercegovačkoj.

\subsection{Dio pučkih proslava u Županiji Zapadnohercegovačkoj}

Na portalu diple.org do početka 2021. godine obrađeni su i dostupni podatci o jednoj pučkoj proslavi koju baštini, posjećuje i živom održava znatan dio žitelja Širokoga Brijega, kao i dio žitelja Mostara.

\section{1) Bilska misa}

Bilska misa kao pučka proslava u širokobriješkom kraju ima posebnu važnost, a pogotovo kod mještana sela Župe Mostarski Gradac i to Dobriča, Donjeg Graca, Gornjeg Graca, Grabove Drage, Gostuše i Prova. ${ }^{95}$ Proslava se održava u Širokom Brijegu, u Grabovoj Dragi, na predjelu brda Velike Bile zvanom Misište na Bilima. Tu se nalazi mala udolina u kojoj je sagrađena kapelica sa zvonikom. Proslava se održava

\footnotetext{
92 Jurilj 2018.

${ }^{93}$ Marić, Ivić, Miloš, Raič 2020: 247-283.

94 Isto.

${ }^{95}$ Marić, Bošnjak, Marić 2017: 32-35.
} 
krajem lipnja ili početkom srpnja nakon završetka blagoslova polja u Župi Mostarski Gradac. ${ }^{96,97}$

Po narodnoj predaji tu se održava misno slavlje i pučka proslava duže od 700 godina. Proslava započinje blagoslovom, ophodom i misnim slavljem. Slijedi užina uz tradicijske poslastice koje pripremaju prisutne domaćice. Nakon užine u udolini pored kapelice plešu se tradicijski plesovi trusa, taraban i proleta, kao i kolanje uz pjevanje i biranje. Svira se na tradicijskim glazbalima diplama i dvojnicama. Pjevaju se tradicijske pjesme ganga, bećarac i brojkavica. Često se čuje i putničko pjevanje. Preko puta Misišta na Bilima, uz staru čatrnju, mladići se natječu u tradicijskim sportovima, i to u bacanju kamena s ramena i potezanju klipa.

Za Bilsku misu posebno je vezana gurmanska poslastica cicvara koja se radi od domaćega sira, domaćega maslaca i brašna. Na ovu pučku proslavu dolazili su i vinari iz Brotnja, koji su na konjima dopremali vino u mišinama, mjehovima, i prodavali ga u drvenim bukarama.

Sudjelovanje u događanjima na Bilskoj misi izravno baštine članovi HKD-a Vrila, kao i mještani okolnih mjesta oko lokaliteta Misišta na Bilima.

\section{Prikaz dijela obrađenih podataka na portalu tkanica.org}

\subsection{Struktura obrađenih podataka na portalu tkanica.org}

Društvo za DTKB u suradnji sa Sekcijom CIOFF®-a za BiH vodi projekt tkanica. org $^{98}$ kojim se prezentiraju baštinici, ${ }^{99}$ njihovi elementi i festivali folklora u $\mathrm{BiH}$ koji djeluju u okrilju CIOFF®-a, odnosno primjenjuju njegove standarde. ${ }^{100} \mathrm{U}$ sklopu Sekcije CIOFF®-a za BiH djeluje ukupno 17 KUD-ova i organizira se pet festivala folklora. Projektom tkanica.org do početka 2021. godine obuhvaćena su tri KUD-a i četiri festivala folklora za koje je prikazan primjer obrađenih podataka. Posebno su obrađene vještine sviranja na tradicijskim glazbalima iz $\mathrm{BiH}$ koja se prikazuju na ovim festivalima.

Namjera je u nastavku realizacije projekta obuhvatiti i preostale KUD-ove i festivale folklora koji se održavaju u $\mathrm{BiH}$ u okrilju CIOFF®-a.

\footnotetext{
${ }^{96}$ Marić, Bošnjak, Marić 2017: 32-35.

${ }^{97}$ Marić, Ivić, Miloš, Raič 2020: 247-283.

${ }^{98}$ http://drustvozadtkb.org/projekti/tkanica-org-2018/ (pristupljeno 20. V. 2021).

${ }^{99}$ https://tkanica.org/bastinici/ (pristupljeno 20. V. 2021).

${ }^{100}$ https://tkanica.org/festivali/ (pristupljeno 20. V. 2021).
} 


\subsection{Kulturno-umjetnička društva}

Projektom tkanica.org do početka 2021. obuhvaćena su tri KUD-a koja redovito sudjeluju u aktivnostima Sekcije CIOFF®-a za BiH, a to su KUDM Bosiljak iz Dervente, KUD Puračić iz Puračića i HKUD Sv. Marko iz Vionice iz Čitluka. ${ }^{101}$ Osnovni podatci o njima nalaze se u nastavku.

Kulturno-umjetničko društvo mladih Bosiljak iz Dervente ili skraćeno KUDM Bosiljak iz Dervente osnovano je 1995., a registrirano 2001. godine. Sjedište ima u Derventi, u Republici Srpskoj u BiH. Član je Sekcije CIOFF®-a za $\mathrm{BiH}^{102}$ i Saveza kulturno-umjetničkih društava Republike Srpske. U dosadašnjem radu kroz ovo je Društvo prošlo nekoliko tisuća članova u različitim sekcijama. U vrijeme izrade ovoga rada 2021. godine predsjednik je KUDM-a bio Bosiljak Tomo Nagradić, a umjetnički voditelj Stana Nagradić. ${ }^{103}$ KUDM Bosiljak na sceni se predstavio u velikom broju zemalja Europe i Azije i sudjelovalo na više CIOFF® i IOV festivala.

U nastupima redovito prezentira elemente NKB-a iz svoga kraja koje baštine njegovi članovi. Tradicijske igre i scenska uprizorenja negdašnje posavske svakodnevice koje izvodi jesu Svadbeni posavski običaj, Šaljiva posavska igra, Posavska zavrzlama i Urankom Đurdele durdilo.

Na nastupima članovi KUDM Bosiljak, kao baštinici, sviraju i na tradicijskim instrumentima šargiji, dvojnicama (svirali) i violini. KUDM Bosiljak na sceni je postavio više tradicijskih običaja iz svoga kraja od kojih se posebno izdvaja običaj koledari ili koledavci koji je detalino opisan u knjizi Tome Nagradića Devren(t)ske pjesme, riječi i običaji objavljene 2020. godine. ${ }^{104}$

KUDM Bosiljak ima i sekciju za koreografirani folklor koja prezentira Mozaik igara iz Republike Srpske i Bosne i Hercegovine, od kojih se posebno ističu Krajiške igre Sitno veze krajiška djevojka, Glamočko starobosansko kolo, Igre iz Bradine Podi bolje kolo moje, Igre iz Posavine Urankom Đurdele durdilo.

Organizatori su CIOFF® festivala folklora pod nazivom Inter-folk-fest Bosiljkovanje Derventa. ${ }^{105}$ KUDM Bosiljak u dosadašnjem radu imao je preko 900 različitih izvedbi kojima je prisustvovalo blizu milijun posjetitelja.

\footnotetext{
${ }^{101}$ https://tkanica.org/bastinici/; (pristupljeno 20. V. 2021).

${ }^{102} \mathrm{CIOFF}{ }^{\circledR} \mathrm{BiH}$ (2020). 10 godina s vama $C I O F F \circledast$, Mostar, USOFFTU u BiH/ Sekcija CIOFF®
} za $\mathrm{BiH}$.

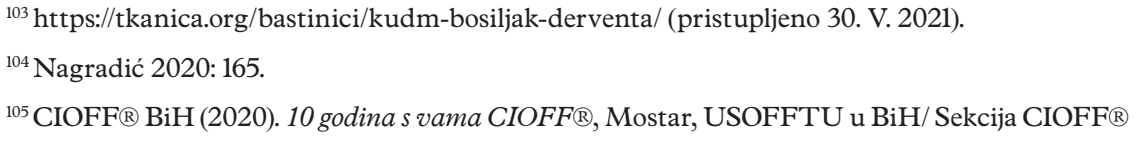




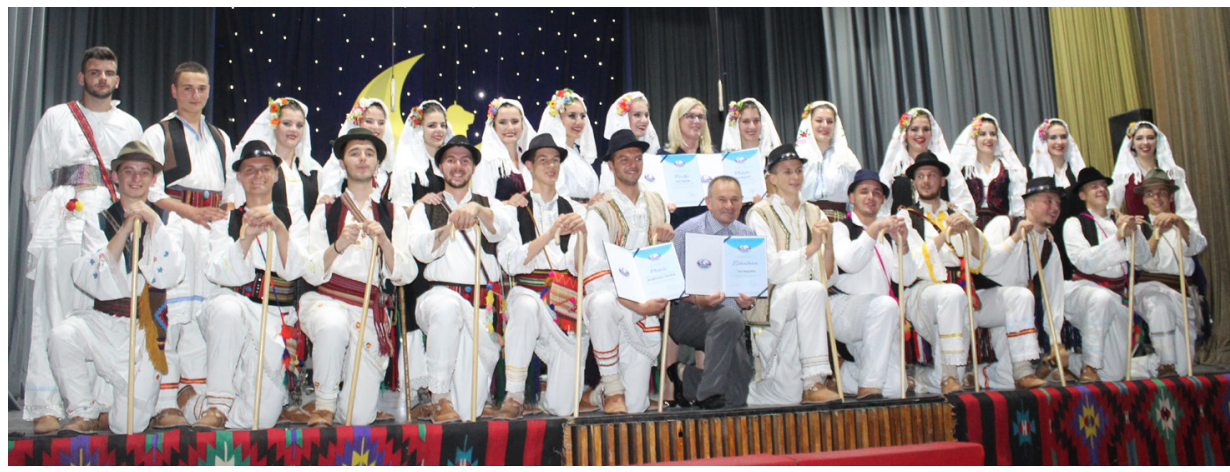

Slika 10. KUDM Bosiljak iz Dervente; Festival povodom 10 godina rada CIOFF® BiH; Sarajevo; pozornica u prostoru Bosanskog kulturnog centra; 7/2019.

Kulturno-umjetničko društvo Puračić iz Puračića ili skraćeno KUD Puračić iz Puračića registrirano je u Tuzlanskom kantonu 2010. godine sa sjedištem u istoimenom mjestu u BiH. ${ }^{106}$ KUD Puračić nastavlja tradiciju KUD-a Jedinstvo koje je na ovom prostoru aktivno djelovalo od sredine prošloga stoljeća do 1992. godine.

Ima više od tristo članova svih dobnih skupina raspoređenih u više različitih sekcija. Nastupali su širom BiH i velikoga broja zemalja Europe i Azije. Član je Sekcije $\mathrm{CIOFF}{ }^{\circledR}$ za BiH. U vrijeme izrade ovoga rada 2021. godine predsjednik je bio Hazim Osmanović, a umjetnički voditelj Nedo Sekulić - Braco. ${ }^{107}$

Društvo u nastupima redovito prezentira elemente NKB-a iz svoga kraja koje baštine njegovi članovi, kao što su tradicijska pjevanja uz saz i izvođenje pjesama sevdalinki. Sviraju na tradicijskim instrumentima šargiji, sazu, dobošu. Uz nastupe sviraju i na violini, gitari i harmonici koji su prešli u tradiciju. Plešu tradicijske plesove iz Puračića i okolice. Imaju i sekciju za koreografirani folklor koja prezentira plesove s drugih prostora Bosne i Hercegovine i regije.

KUD Puračić organizator je Međunarodnoga festivala folklora Dani ćaske Puračic ${ }^{108}$ i gastro manifestacije Puračko ćaskanje s ciljem očuvanja tradicijskoga jela puračka ćaska. Njegovi članovi priredili su i izdali knjigu recepata tradicijskih jela pod nazivom Puračka sofra 2019. godine sa šezdeset gastro specijaliteta puračkoga kraja. U prosincu 2020. godine upisali su Puračku ćasku-umijeće pripremanja i služenja na Listu nematerijalne kulturne baštine Bosne i Hercegovine. ${ }^{109}$

\footnotetext{
${ }^{106}$ Isto.

${ }^{107}$ https://tkanica.org/bastinici/kud-puracic/ (pristupljeno 30. V. 2021).

${ }^{108} \mathrm{CIOFF}{ }^{\circledR} \mathrm{BiH}$ (2020). 10 godina s vama CIOFF®, Mostar, USOFFTU u BiH/ Sekcija CIOFF ${ }^{\circledR}$
} za BiH.

${ }^{109}$ KUD Puračić (2020). Puračka sofra, Puračić, KUD Puračić. 


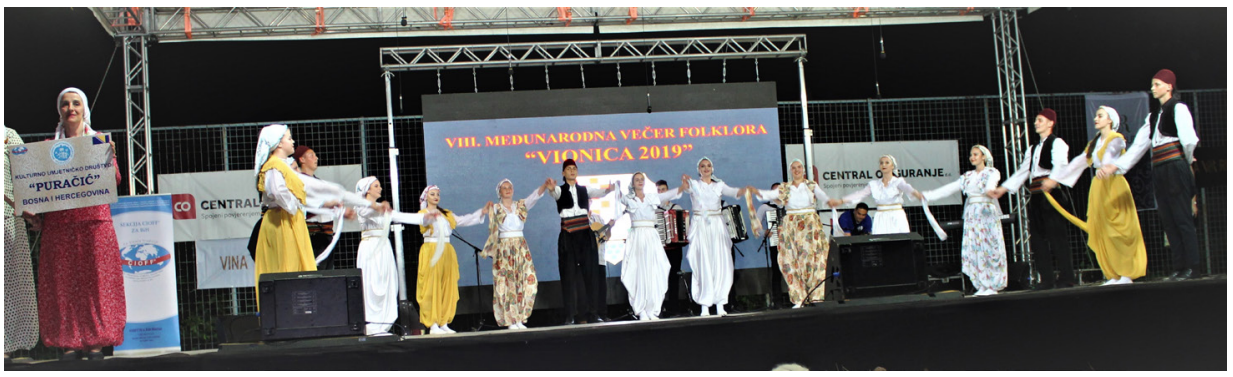

Slika 11. KUD Puračić; 8. Međunarodna večer folklora - Vionica 2019.; Vionica, Čitluk; pozornica na igralištu osnovne škole u Vionici; 7/2019.

Hrvatsko kulturno-umjetničko društvo Sv. Marko iz Vionice Čitluk ili skraćeno HKUD Sv. Marko iz Vionice iz Čitluka osnovano je 2011. godine. ${ }^{110}$ Sjedište mu je u mjestu Vionici u Čitluku u BiH. Član je Sekcije CIOFF®-a za BiH. Ima oko sto članova organiziranih u više sekcija. U vrijeme izrade ovoga rada 2021. godine predsjednik je bio HKUD-a Sv. Marko iz Vionice Damir Mandarić, a umjetnički voditelji Ivan Barać i Jure Miloš. ${ }^{111}$ Društvo se na sceni predstavilo širom BiH i više europskih zemalja.

Na nastupima redovito promovira elemente NKB-a svojega kraja koje baštine njegovi članovi. Na nastupima se prakticiraju tradicijski plesovi trusa, taraban i vionica. Tu su i tradicijska pjevanja ganga, bećarac, brojka ili brojkavica, čobanske pjesme i svatovske pjesme. Redovito se svira na tradicijskom glazbalu diple.

HKUD Sv. Marko iz Vionice organizator je festivala folklora pod nazivom Međunarodne večeri folklora u Vionici - Čitluk. ${ }^{112}$

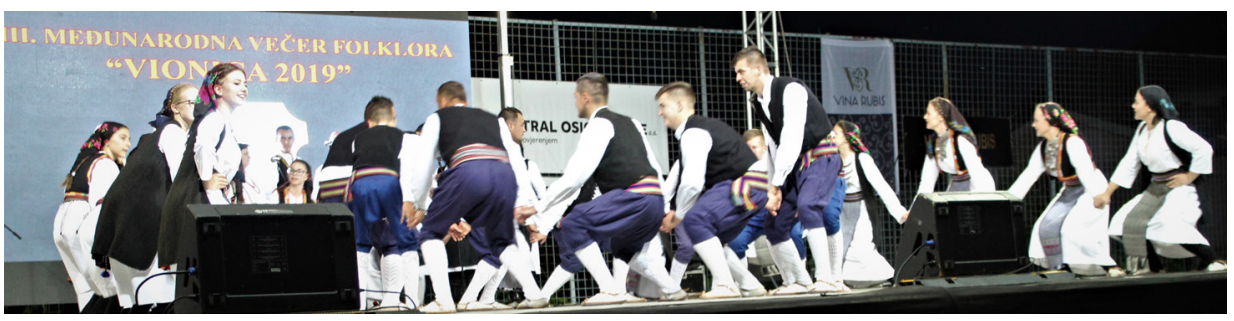

Slika 12. HKUD Sv. Marko iz Vionice; 8. Međunarodna večer folklora - Vionica 2019; Vionica, Čitluk; pozornica na igralištu osnovne škole u Vionici; 7/2019. za BiH.

${ }^{110} \mathrm{CIOFF}{ }^{\circledR} \mathrm{BiH}$ (2020). 10 godina s vama $\mathrm{CIOFF}{ }^{\circledR}$, Mostar, USOFFTU u BiH/ Sekcija CIOFF®

${ }^{111}$ https://tkanica.org/bastinici/hkud-vionica/ (pristupljeno 30. V. 2021).

${ }^{112} \mathrm{CIOFF} \AA \mathrm{BiH}$ (2020). 10 godina s vama CIOFF®, Mostar, USOFFTU u BiH/ Sekcija CIOFF® za $\mathrm{BiH}$. 


\subsection{Festivali folklora}

Projektom tkanica.org do početka 2021. godine prikupljeni su i obrađeni osnovni podaci o četirima festivalima iz $\mathrm{BiH}$ koji se odvijaju po $\mathrm{CIOFF}{ }^{\circledR}$-ovim preporukama: Inter-folk-fest Bosiljkovanje Derventa, Medunarodni festival folklora Dani ćaske Puračić, Medunarodne večeri folklora u Vionici - Čitluk i Festival Sekcije CIOFF®-a $B i H .{ }^{113}$ Svaki od ovih festivala ima međunarodni karakter. Posebna je važnost događanja koja se odvijaju u okrilju CIOFF®-a sudjelovanje izvođača iz inozemstva, promocija i razmjena programa organizatora na međunarodnoj razni kao i sudjelovanje u CIOFF ${ }^{\circledR}$-ovim projektima na globalnoj razini koji se odvijaju u okrilju UNESCO-a. Na svakom od ovih festivala predstavljaju se i baštinici iz mjesta održavanja festivala uz predstavljanje elemenata NKB-a svojega kraja. Sažetak obrađenih materijala o ovim festivalima nalazi se u nastavku.

Inter-folk-fest Bosiljkovanje održava se u Derventi i susjednim gradovima u organizaciji KUDM-a Bosiljak iz Dervente. U kalendar CIOFF®-a ušao je 2005. godine, a od 2012. godine jedini u $\mathrm{BiH}$ posjeduje CIOFF®-ov certifikat za festival folklora koji se izdaje na deset godina.

Festival je održan 13. listopada 2019. godine u Derventi pod nazivom 23. Inter folk festival Bosiljkovanje 2019. Na njemu su sudjelovali izvođači iz četiriju država: KUDM Bosiljak Derventa iz BiH, SKUD Semberija iz Bijeljine iz BiH, Radničko KUD Proleter iz Sarajeva iz BiH, KUD Nikola Tesla iz Postojne iz Slovenije, Zavičajni klub Žeravac iz Slavonskoga Broda iz Hrvatske, KUD Srem iz Jakova/Beograd iz Srbije. Festival je raznovrstan po svom sadržaju.

Derventa obiluje raznovrsnim prirodno-kulturnim znamenitostima interesantnim posjetiteljima. Od njih se posebno ističu Etno selo Eden s idilom i čari negdašnjega posavskoga sela kao i žubor rijeke Ukrine kroja prolazi kroz posavske proplanke obrasle šumom. Derventa je poznata i po izletištu i motelu na Babinu brdu nedaleko od centra grada. Tu je i Derventski velikogospojinski vašar, čija je tradicija duga oko 170 godina. Iz Dervente dolaze i najpoznatiji i najstariji izvorni pjevači posavskih pjesama, braća Begić iz Dervente, što je opisano u knjizi Tome Nagradića Devren(t)ske pjesme, riječi i običaji objavljene 2020. godine. ${ }^{114}$ Oni su snimili i objavili prvu ploču posavskih pjesama 1969. godine.

\footnotetext{
${ }^{113}$ https://tkanica.org/festivali/ (pristupljeno 20. V. 2021).

${ }^{114}$ Nagradić 2020: 11.
} 
Medunarodni festival folklora Dani ćaske - Puračić organizira KUD Puračić iz istoimenoga mjesta. ${ }^{115}$

Do 2020. godine održano je devet festivala na kojima je sudjelovalo više od sto folklornih ansambala iz Bosne i Hercegovine i inozemstva.

Deveti put zaredom festival je održan od 31. srpnja do 4. kolovoza 2019. godine pod nazivom 9. Internacionalni festival folklora Dani ćaske Puračić 2019. Na festivalu su sudjelovali izvođači iz pet država: KUD Puračić iz BiH, KUD Gradina Gradišće iz Zenice iz BiH, BKUD Azra Rašljani iz Brčkog iz BiH, KUD Mladi Rudar iz Dobrinje iz BiH, KUD Zmaj od Bosne iz Gradačca iz BiH, DYFTA Rodopchanka iz Devina iz Bugarske, KUD Izvorni običaji iz Zagreb iz Hrvatske, FA Danilovgrad iz Danilovgrada iz Crne Gore, Edirne Belediyesi Halk Oyunlari Edirne iz Turske.

Puračić posjetiteljima nudi brojne znamenitosti od kojih se posebno ističu dva nacionalna spomenika $\mathrm{BiH}$, i to stara bosanska kuća s čardakom među rogovima Čamdžića kuća i Hram sv. Proroka Ilije. Tu su još i etno soba Puračka sehara u centru Puračića koja oslikava unutrašnjost jedne tradicionalne kuće ovog kraja. Od događanja tu je Vašar-sajam u Puračiću s tradicijom dugom preko 160 godina i redovito se održava od 12. do 14. listopada uz prisustvo blizu 200000 posjetitelja, što predstavlja najveće narodno okupljanje u ovim krajevima. Iz Puračića svakako treba istaknuti i tradicijski gastro specijalitet puračku ćasku, koji je upisan na Listu nematerijalne kulturne baštine Bosne i Hercegovine. ${ }^{116}$

Medunarodne večeri folklora $\boldsymbol{u}$ Vionici u Čitluku organizira HKUD Sv. Marko iz istoimenog mjesta. ${ }^{17}$

Osmi put za redom održan je 6. i 7. srpnja 2019. godine pod nazivom 8. Medunarodna večer folklora - Vionica 2019. Na festivalu su sudjelovali izvođači iz triju država: HKUD sveti Marko iz Vionice iz Čitluka iz BiH, KUD Puračić iz Puračića iz $\mathrm{BiH}, \mathrm{HKUD}$ Topala iz Viteza iz $\mathrm{BiH}$, HKUD Čeljevo iz Čapljine iz $\mathrm{BiH}$, KUD Usora iz Usore iz BiH, HKUD Luke Čapliina - Višnjići iz BiH, KUD Jedinstvo iz Splita iz Hrvatske, Vukšićki bećari iz Hrvatske, KUD Aluminij iz Podgorice iz Crne Gore, Ansambl narodnih pjesama i plesova Hrvatske Lado iz Zagreba iz Hrvatske.

U blizini Vionice u čitlučkom kraju nalazi se i Vinski muzej i etno zbirka u Gradnićima, Etno selo Herceg koje posjetiteljima dočarava idilu negdašnjega herce-

${ }^{115} \mathrm{CIOFF} \AA \mathrm{BiH}$ (2020). 10 godina s vama CIOFF®, Mostar, USOFFTU u BiH/ Sekcija CIOFF® za BiH.

${ }^{116}$ KUD Puračić (2020). Puračka sofra, Puračić, KUD Puračić.

${ }^{117} \mathrm{CIOFF} \AA \mathrm{BiH}$ (2020). 10 godina s vama CIOFF®, Mostar, USOFFTU u BiH/ Sekcija CIOFF® za BiH. 
govačkog sela, kao i globalno poznato turističko mjesto i svetište ukazanja Blažene Djevice Marije u Međugorju.

Festival Sekcije CIOFF®-a BiH organizira Sekcija CIOFF®-a za BiH. ${ }^{118}$ Prvi je put održan 2019. godine u Sarajevu pod nazivom Festival povodom 10 godina rada CIOFF® BiH. Na festivalu su sudjelovali izvođači iz BiH:119 HKUD Hercegovac Široki Brijeg, RKUD Proleter-Sarajevo, KUD Puračić-Puračić, KUD Baščaršija Sarajevo, KUD Mladost Banja Luka Zalužani, KUD Igman - Hadžići, KUDM Bosiljak-Derventa, interpretatorka sevdalinke Ramiza Milkunić iz Tuzle i interpretator sevdalinke Hazim Osmanović iz Puračića. Festival je bio praćen i od strane stručne međunarodne javnosti koja djeluje po CIOFF®-ovim i UNESCO-ovim preporukama.

Sarajevo obiluje brojnim kulturno-prirodnim znamenitostima od kojih se ističu brojni muzeji, spomenici, parkovi, stare građevine, planine, a posebno stari dio grada Baščaršija kao i izvor rijeke Bosne.

\subsection{Prikaz umijeća sviranja na tradicijskim glazbalima}

Na portalu tkanica.org Društvo za DTKB provodi u suradnji sa Sekcijom mladih CIOFF ${ }^{\circledR}$-a BiH također prikupljanje, obradu, digitalizaciju i objavu podataka o umijeću sviranja na tradicijskim glazbalima iz $\mathrm{BiH}$ koja se pojavljuju na festivalima folklora. Tradicijska glazbala opisana su na način kako to čine sami tradicijski glazbenici, odnosno baštinici umijeća sviranja na tom glazbalu.

Do početka 2021. godine obrađeni su materijali o umijeću sviranja na sedam tradicijskih glazbala i to za: ćurlik, diple, gusle, lijerica, saz, svirala, šargija. ${ }^{120}$

Pojedinačni opisi umijeća sviranja na tradicijskim glazbalima sastoje se od zvučnog zapisa sviranja, fotografije glazbala i glazbenika, osnovnih tekstualnih podataka o samom glazbalu, imenu glazbenika i imenu sakupljača materijala. Primijenjeni koncept obrade i prezentacije podataka omogućava i dodavanje materijala za nova glazbala kao i izradu registra registra/popisa tradicijskih glazbenika baštinika koji sviraju na pojedinim glazbalima.

Sekcije mladih $\mathrm{CIOFF}{ }^{\circledR}-\mathrm{a} \mathrm{BiH}$ od obrađenih materijala o tradicijskim glazbalima izrađuje posebne uvećane fotografije s tekstualnim opisima i QR-kodovima koje su namijenjene za izložbe u okviru festivala folklora i sličnih događanja na kojima se prezentira tradicijska kulturna baština. Uz fotografiju tradicijskoga instrumenta i

${ }^{118}$ CIOFF ${ }^{\circledR} \mathrm{BiH}$ (2020). 10 godina s vama CIOFF®, Mostar, USOFFTU u BiH/ Sekcija CIOFF® za BiH

\footnotetext{
${ }^{119}$ https://tkanica.org/festivali/festival-cioff-a-bih/ (pristupljeno 30. svibnja 2021.).

${ }^{120}$ https://tkanica.org/instrumenti/sargija/ (pristupljeno 20. V. 2021).
} 
glazbenika nalazi se njegov kratak opis, ime glazbenika i mogućnost slušanja zvučnog zapisa pomoću mobitela i QR koda na slici. Informacije o ovim aktivnostima mogu se naći i na službenim mrežnim stranicama UNESCO-a. ${ }^{121}$

U nastavku je primjer opisa za tradicijsko glazbalo šargije. ${ }^{122}$

Šargija je žičano tradicijsko glazbalo. Osnovni su mu dijelovi rezonantno tijelo i drška. Rezonantno tijelo ustvari je kutla preko koje je postavljena daska na kojoj su izbušeni otvori, odnosno glasnice. Kutla se većinom izrađuje od drveta javora, trešnje ili šljive, a daska ili ploča od jelovine. Na dršci se nalazi 13 perdeta ili pregradica, koje dijele polja po kojima se prstima pritišću žice. Polja znaju biti označena točkama radi lakšeg raspoznavanja tonova. Zvuk se postiže okidanjem žice terzijanom napravljenim od komada goveđeg roga ili trešnjine kore. Šargija može imati četiri i više žica ovisno o vrsti. Naime, postoje manje i veće šargije te se najbolji zvuk postiže kada dva svirača sviraju u kombinaciji, jedan manju, a drugi veću šargiju uz raznovrsne tehnike sviranja.

Šargija se svira u mnogobrojnim prigodama uz pjesmu i kao pratnja plesu. $\mathrm{Na}$ slici 13. je šargijaš Drago Mišković iz Usore. ${ }^{123}$

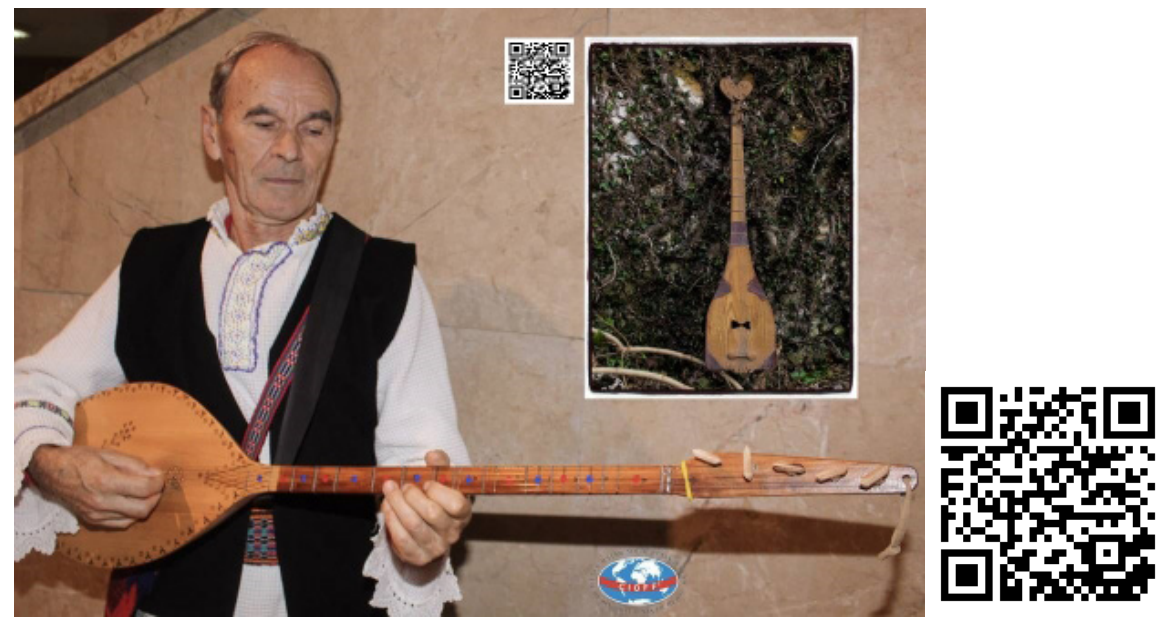

Slika 13. Šargijaš Drago Mišković iz Usore, 2019.

(preko QR kodova na slici moguće je poslušati zvuk svakoga instrumenta)

${ }^{121}$ https://drustvozadtkb.org/projekti/vrila-tradicisjkog-naslijeda-2017-siroki-brijeg-znanstvenostrucni-skup/ (pristupljeno 21. II. 2021).

${ }^{122}$ https://tkanica.org/bastinici/ (pristupljeno 20. V. 2021).

${ }^{123}$ Isto. 


\section{Zaključak}

Portali diple.org i tkanica.org s dostupnim materijalima o elementima nematerijalne kulturne baštine u Bosni i Hercegovini znatno pridonose pozitivnoj promociji kraja iz kojega elementi potječu. Primijenjena metodologija prikupljanja, obrade i objave podataka, uz izgrađenu mrežu partnera i sudjelovanje mnogobrojnih baštinika elemenata nematerijalne kulturne baštine na terenu, aktivnostima daje prepoznatliivost i posebnu vrijednost.

Istraživanje je pokazalo kako su KUD-ovi koji ulažu više napora u istraživanje i obradu materijala o nematerijalnoj kulturnoj baštini uspjeli očuvati kontinuitet u radu i dodatno pozitivno promovirati mjesto i kraj iz kojega dolaze.

Korištenje novih digitalnih tehnologija u popularizaciji tradicijske kulturne baštine tematiku na pristupačniji način prezentira mladim naraštajima i doprinosi njihovu većem angažmanu u radu KUD-ova i udruga koji djeluju na području očuvanja tradicijske kulturne baštine.

Prepoznatlijost nematerijalne kulturne baštine jednoga mjesta pridonosi njegovu pozitivnom predstavljanju, povećanju interesa šire javnosti kao i izgradnji statusa poželjne turističke destinacije za posjetitelje.

Tradicijska kulturna baština jednog kraja predstavlja njegov veliki potencijal. $\mathrm{Na}$ osnovi prikupljenih materijala pojedini elementi tradicijske kulturne baštine mogu se ukomponirati u gospodarski samoodržive projekte koji mogu osigurati ostvarivanje novih prihoda kao i otvaranje novih radnih mjesta.

Ovaj rad, kao i dostupni materijali na portalima diple.org i tkanica.org mogu poslužiti i kao podrška u sistematičnom pristupu prepoznavanja i izrade službenih popisa elemenata nematerijalne kulturne baštine, kako na regionalnim razinama tako i na državnoj, naročito zbog kompleksnosti administrativnoga ustroja Bosne i Hercegovine. 


\section{LITERATURA}

Barać, Ivan (2020). Plesna i instrumentalna tradicija Širokog Brijega, Zbornik radova predavača sa Seminara folklora Hrvata u $\mathrm{BiH}$, Mostar, UHAKUD u BiH, str. 105-115.

CIOFF® BiH (2020). 10 godina s vama $C I O F F \circledR$, Mostar, USOFFTU u BiH/ Sekcija CIOFF® za BiH.

Češkić, Ana (2020). Dječje igre, brojalice, biralice, svirala i igračke iz sela Mokrog kod Širokog Brijega, Zbornik radova predavača sa Seminara folklora Hrvata u BiH, Mostar, UHAKUD u BiH, str. $117-136$.

Hrovatin, Mirela (2015). Višeslojnost provedbe programa očuvanja nematerijalne baštine u Hrvatskoj na primjeru ojkanja (gange), Zbornik radova Dana europskog naslijeđa u BiH, Federalno ministarstvo kulture Sarajevo; str. 14-56.

Jurilj, Zorica (2018). Grabovina tilovinu pita. Tradicijska kulturna baština širokobriješkog kraja, Široki Brijeg, Ogranak Matice hrvatske Široki Brijeg.

Kraljević, Ante (2017). Ganga - s izvora glasa, Grude, Udruga DAVORIJA - DAN d.o.o.

Kraljević, Ante (2020). Ganga - jedinstveno pučko dvoglasje - sažetci, Zbornik radova predavača sa Seminara folklora Hrvata u BiH, Mostar, UHAKUD u BiH, str. 45-61.

KUD Puračić (2020). Puračka sofra, Puračić, KUD Puračić.

Nagradić, Toma (2020). Derven(t)ske pjesme, riječi i običaj, Banja Luka, Izdavačka kuća Besjeda.

Marić, Toni (2008). Multimedijalna prezentacija izvornih kulturno-umjetničkih društava na Internetu, 1. Medunarodni simpozij digitalizacija kulturne baštine Bosne i Hercegovine, Sarajevo, ETF, str. 157-159.

Marić, Toni (2019). Kulturno-umjetnička društva na području Širokog Brijega, Vitko, 18, Široki Brijeg, Ogranak Matice hrvatske Široki Brijeg, str. 47-51.

Marić, Toni (2020). Digitalizacija elemenata nematerijalne kulturne baštine širokobrijeških sela Župe Mostarski Gradac, Vitko, 19, Široki Brijeg, Ogranak Matice hrvatske Široki Brijeg, str. 43-47.

Marić, Toni, Bošnjak, Vlado, Marić, Vlado (2017). Pučke obljetnice na području širokobrijeških sela župe Mostarski Gradac, Vitko, 16, Široki Brijeg, Ogranak Matice hrvatske Široki Brijeg, str. $32-35$.

Marić, Toni, Ivić, Anto, Miloš, Jure, Raič, Anka (2020). Digitalizacija sadržaja o nematerijalnoj kulturnoj baštini, Zbornik radova predavača sa Seminara folklora Hrvata u BiH, Mostar, UHAKUD u BiH, str. 247-283.

Marić, Toni, Ostojić, Željko, Marić, Marina (2010). Izgradnja multimedijalne baze izvornih tradicijskih kulturno-umjetničkih stvaratelja, 2. Međunarodni simpozij digitalizacija kulturne baštine Bosne i Hercegovine, Sarajevo, ETF, str. 120-123.

Miloš, Jure (2015). Ganga danas (iz ugla prenositelja i izvođača), Zbornik radova Dana europskog naslijeda u BiH, Federalno ministarstvo kulture Sarajevo, str. 79-90.

Miloš, Jure (2020). Ganga - Jučer. Danas, sutra, Zbornik radova predavača sa Seminara folklora Hrvata u BiH, Mostar, UHAKUD u BiH, str. 61-70.

Raič, Anka (2005). Očuvanje nematerijalne baštine Hrvata BiH kroz aktivnosti UHAKUD u BiH, Enter Nous, 2/2005, Larnaka, CIOFF ${ }^{\circledR}$ Sektor J. Europe i Afrike, str. 10-12.

Raič, Anka (2010). Sustav zaštite i očuvanja nematerijalne kulturne baštine u BiH, Zbornik četvrte konferencije o integrativnoj zaštiti, Banja Luka, Republički zavod za zaštitu kulturno-istorijskog i prirodnog naslijeđa Banja Luka, str. 170-183.

Raič, Anka (2015). Standardizacija međunarodnih festivala folklora i uloga CIOFF®-a u očuvanju gange, Zbornik radova Dana europskog naslijeda u BiH, Federalno ministarstvo kulture Sarajevo, str. 57-70. 
Rihtman, Dunja (1970). Narodna muzička tradicija lištičkog područja, Glasnik Zemaljskog muzeja BiH u Sarajevu - Etnologija, XXIV/XXV, Sarajevo, Zemaljski muzej Bosne i Hercegovine, str. 363-417.

Rotim, Karlo (1995). Župa Mostarki Gradac, Široki Brijeg, TP Franjo Kluz.

Soldo, Maja (2015). Rezultati istraživanja srednjovjekovne grobne crkve na lokalitetu Varda, Knešpolje u Širokom Brijegu, Naše starine, XXIII, Sarajevo, Zavod za zaštitu spomenika, str. 11-25.

UNESCO (2003). Konvencija o očuvanju nematerijalne kulturne baštine, Pariz, UNESCO, 17. listopada 2003.

Vidović, Vedran (2015): Kulturno-umjetnička društva-čuvari nematerijalne kulturne baštine, Zbornik radova Dana europskog naslijeđa u BiH, Federalno ministarstvo kulture Sarajevo, str. 71-78.

Vladić-Mandarić, Lidija, Miloš, Jure, Vidović, Vedran (2020). Pregled djelatnosti Udruge hrvatskih amaterskih kulturno-umjetničkih društava u Bosni i Hercegovini (UHAKUD U BiH), Zbornik radova predavača sa Seminara folklora Hrvata u BiH, Mostar, UHAKUD u BiH, str. 15-35.

\section{MREŽNI IZVORI}

Društvo za DTKB: https://drustvozadtkb.org/projekti/strucni-skup-o-ocuvanju-elemenata-nematerijalne-kulturne-bastine-siroki-brijeg-2019/ (pristupljeno 21. II. 2021).

Društvo za DTKB, VTN 2017: https://drustvozadtkb.org/projekti/vrila-tradicisjkog-naslijeda-2017-siroki-brijeg-znanstvenostrucni-skup/ (pristupljeno 21. II. 2021).

Društvo za DTKB; projekt diple.org: https:/drustvozadtkb.org/projekti/diple-org-2013/ (pristupljeno 20. V. 2021).

Društvo za DTKB; projekt tkanica.org: http://drustvozadtkb.org/projekti/tkanica-org-2018/ (pristupljeno 20. V. 2021).

Društvo za DTKB: http://drustvozadtkb.org/ (pristupljeno 20. V. 2021).

Grad Široki Brijeg: http://www.sirokibrijeg.ba/index.php/vijesti/1482-odrzan-znanstveno-strucni-skupa-vrila-tradicijskog-naslijeda (pristupljeno 20. V. 2021).

Međunarodni CIOFF: http://www.CIOFF®.org/contact-section.cfm?id=209 (pristupljeno 20. V. 2021).

Ministarstvo obrazovanja, znanosti, kulture i športa Županije Zapadnohercegovačke: https://mozks-zzh. com/2019/10/28/strucni-skup-o-ocuvanju-elemenata-nematerijalne-kulturne-bastine/ (pristupljeno 20. V. 2021).

Portal diple.org: www.diple.org (pristupljeno 20. V. 2021).

Portal diple.org; popis elemenata NKB: http://diple.org/index.php/hr/popisi-enkb (pristupljeno 20. V. 2021).

Portal diple.org; pdf izdanje Diplar: http://diple.org/images/DOWN/DIPLAR-2013-09-30-v401.pdf; (pristupljeno 21. II. 2021).

Portal diple.org; HKUD-ovi: http://diple.org/index.php/hr/hkud-ovi/ (pristupljeno 20. V. 2021).

Portal diple.org; festivali folklora: http://diple.org/index.php/hr/festivali-folklora (pristupljeno 20. V. 2021).

Portal diple.org; popis jednog broja karakterističnih elemenata NKB za ŽZH: http:/diple.org/index.php/ hr/popisi-enkb/115-popis-enkb-za-podrucje-zzh (pristupljeno 20. V. 2021).

Portal diple.org; Božićno silo u Grudama 2019: http:/diple.org/index.php/hr/festivali-folklora/84-bozicno-silo-u-grudama (pristupljeno 30. V. 2021).

Portal diple.org; predstavljanje HKUD Tihaljina iz Tihaljine, Grude: http://diple.org/index.php/hr/ hkud-ovi/119-hrvatsko-kulturno-umjetnicko-drustvo-tihaljina-iz-tihaljine (pristupljeno 30 . V. 2021). 
Portal diple.org; predstavljanje KUD Mokro iz Širokog Brijega: http://iple.org/index.php/hr/hkudovi/120-kulturno-umjetnicko-drustvo-mokro-siroki-brijeg (pristupljeno 30. V. 2021).

Portal diple.org; predstavljanje HKUD Hercegovac iz Širokog Brijega: http://diple.org/index.php/hr/ hkud-ovi/118-hrvatsko-kulturno-umjetnicko-drustvo-hercegovac-iz-sirokog-brijega (pristupljeno 30. V. 2021).

Portal diple.org; predstavljanje HKD Vrila iz Širokog Brijega: http://diple.org/index.php/hr/hkudovi/117-hrvatsko-kulturno-drustvo-vrila-siroki-brijeg (pristupljeno 30. V. 2021).

Portal tkanica.org; predstavljanje KUDM Bosiljak iz Dervente: https://kanica.org/bastinici/kudm-bosiljak-derventa/ (pristupljeno 30. V. 2021).

Portal tkanica.org; predstavljanje HKUD Sv. Marko Vionica iz Čitluka : https://tkanica.org/bastinici/ hkud-vionica/ (pristupljeno 30. V. 2021).

Portal tkanica.org; predstavljanje KUD Puračić iz Puračića: https://tkanica.org/bastinici/kud-puracic/ (pristupljeno 30. V. 2021).

Portal tkanica.org; predstavljanje Festivala Sekcije CIOFF-a BiH u Sarajevu: https://tkanica.org/festivali/ festival-cioff-a-bih/ (pristupljeno 30. V. 2021).

Portal tkanica.org: www.tkanica.org (pristupljeno 20. V. 2021).

Portal tkanica.org; opis tradicijskog glazbala šargije: https://kanica.org/instrumenti/sargija/ (pristupljeno 20. V. 2021).

Portal tkanica.org opis rada KUD-ova baštinika: https://kanica.org/bastinici/ (pristupljeno 20. V. 2021).

Portal tkanica.org; popis festivala: https://tkanica.org/festivali/_(pristupljeno 20. V. 2021).

Udruga Davorija: https:/udruga-davorija.com/ (pristupljeno 20. V. 2021).

Udruga Davorija; Božićno silo 2019: https://udruga-davorija.com/bozicno-silo-2019/ (pristupljeno 30. V. 2021).

UHAKUD u BiH: http://uhakud.info/ (pristupljeno 20. V. 2021).

UNESCO: https://ich.unesco.org/en/living-heritage-experience-and-covid-19-pandemic-01124?id=00257 (pristupljeno 20. V. 2021).

UNESCO: https:/ich.unesco.org/en/living-heritage-experience-and-covid-19-pandemic-01124?id=00380 (pristupljeno 20. V. 2021). 


\title{
PORTALS AND DATABASES ON ELEMENTS OF CULTURAL HERITAGE AT FOLKLORE FESTIVALS
}

\author{
Toni Marić \\ Society for Digitisation of Traditional Cultural Heritage, Široki Brijeg \\ toni.maric@tel.net.ba \\ Anka Raič \\ CIOFF® Section for Bosnia and Herzegovina, Mostar \\ raicanka@gmail.com \\ Vedran Vidović \\ Association of Croatian Amateur Cultural Clubs in Bosnia and Herzegovina, Mostar \\ vidovic.vedran@medjugorje.hr \\ Mirela Šečić \\ Federal Ministry of Culture and Sports, Sarajevo \\ mirela.secic@fmks.gov.ba
}

\begin{abstract}
The paper describes the method of collecting, processing and digitising materials on intangible cultural heritage presented at folklore festivals and the construction of multimedia databases and portals for their promotion. These activities make certain elements of intangible cultural heritage and cultural and artistic societies as their heirs more visible and accessible to the public, while giving additional incentives to the heirs themselves to pass them on to young generations. This is carried out by the Society for the Digitisation of Traditional Cultural Heritage from Siroki Brijeg in cooperation with partners and the heirs of the elements through two projects. The first project, diple.org, is being in cooperation with the Association of Croatian Amateur Cultural and Artistic Societies in B\&H and presents the traditional cultural heritage of Croats in $\mathrm{B} \& \mathrm{H}$. The second project, tkanica.org, presents the heirs, their elements and folklore festivals in $\mathrm{B} \& \mathrm{H}$ that operate under the auspices of CIOFF ${ }^{\circledR}$ and is in cooperation with the $\mathrm{CIOFF}{ }^{\circledR}$ Section for $\mathrm{B} \& \mathrm{H}$. The projects have so far covered over two hundred heirs. More detailed data on seven cultural and artistic societies, seven folklore festivals, two lists of a number of characteristic elements at the sites as well as a list of playing skills on seven traditional instruments were processed. The realisation of the previous part of the project showed that the heirs of the elements that invest significant efforts in field research on the elements of intangible cultural heritage of their region managed to maintain continuity in work and further draw positive public attention to their heritage.
\end{abstract}

Keywords: cultural heritage elements; inheritors; databases; digitisation 